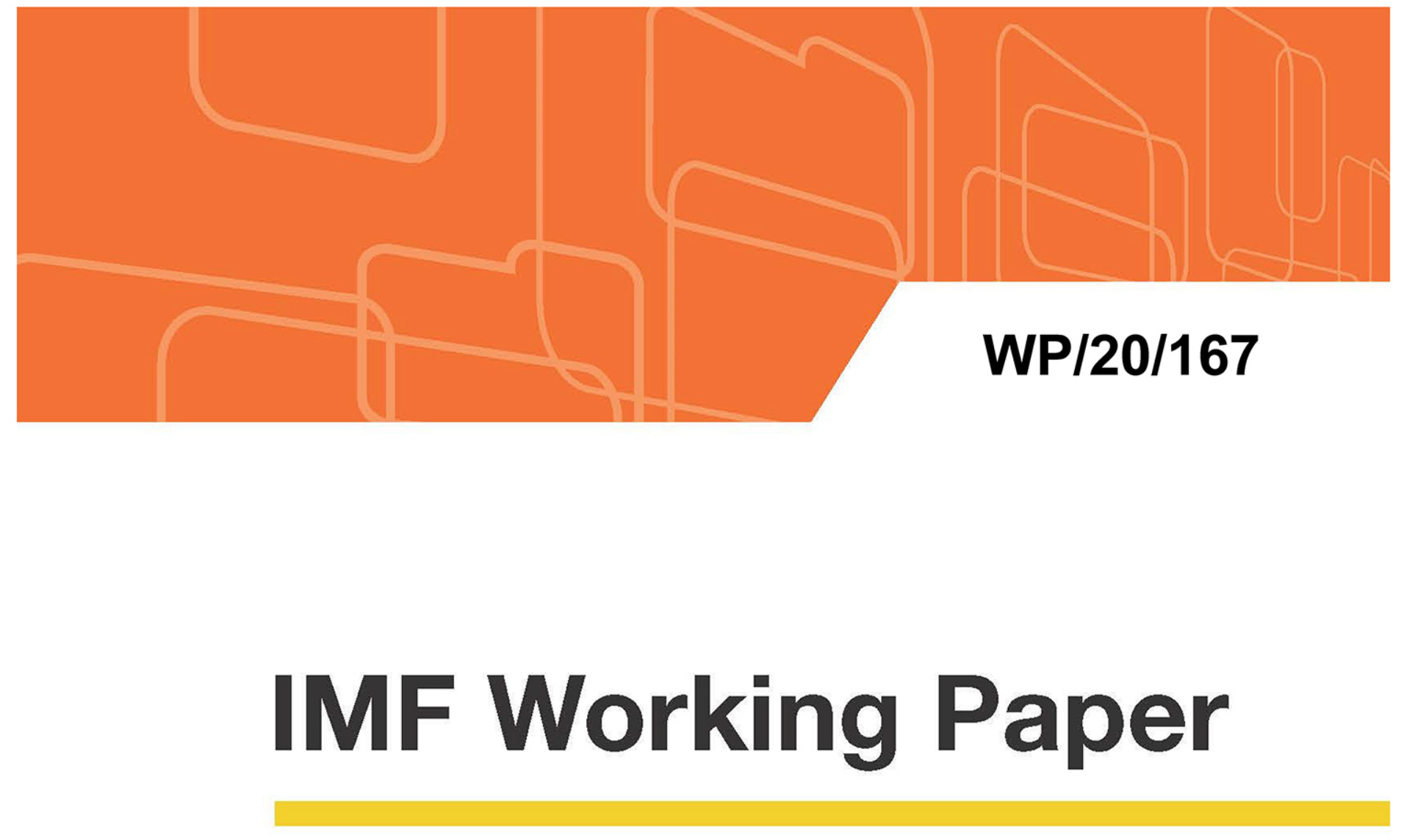

\title{
Tunisia Monetary Policy Since the Arab Spring: The Fall of the Exchange Rate Anchor and Rise of Inflation Targeting
}

by Mariam El Hamiani Khatat, Nicolas End, and Rym Kolsi

IMF Working Papers describe research in progress by the author(s) and are published to elicit comments and to encourage debate. The views expressed in IMF Working Papers are those of the author(s) and do not necessarily represent the views of the IMF, its Executive Board, or IMF management. 


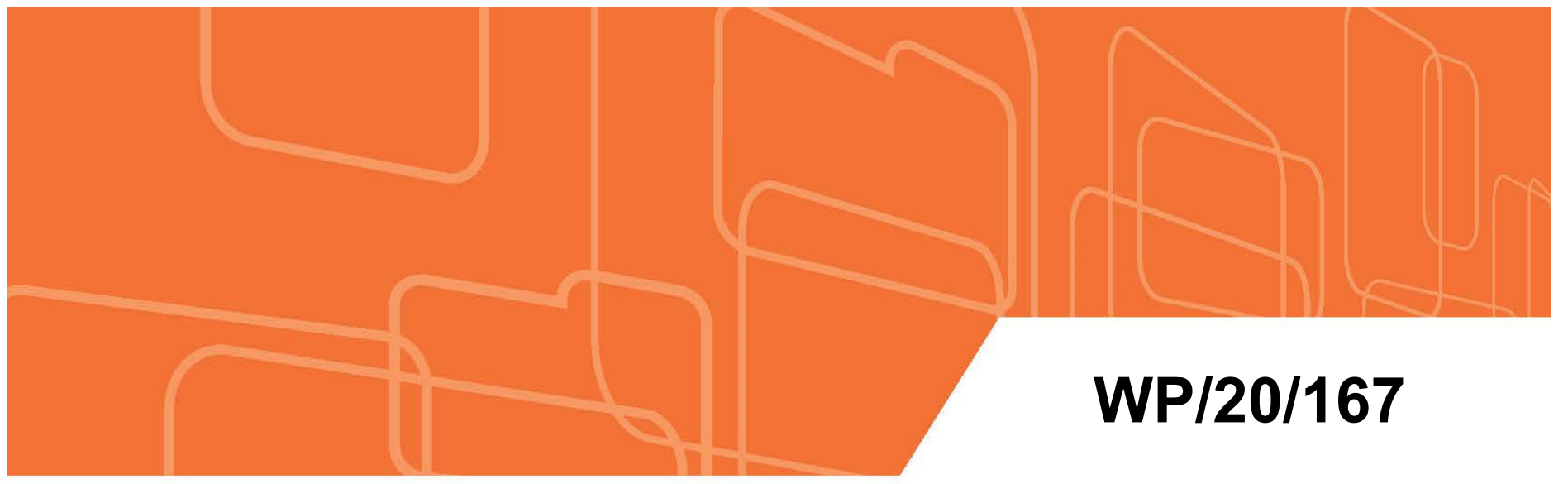

\section{IMF Working Paper}

\section{Tunisia Monetary Policy Since the Arab Spring: The Fall of the Exchange Rate Anchor and Rise of Inflation Targeting}

by Mariam El Hamiani Khatat, Nicolas End, and Rym Kolsi

IMF Working Papers describe research in progress by the author(s) and are published to elicit comments and to encourage debate. The views expressed in IMF Working Papers are those of the author(s) and do not necessarily represent the views of the IMF, its Executive Board, or IMF management.

$$
\text { I N T E R N A T | O N A L M O N E T A R Y F U N D }
$$




\title{
IMF Working Paper
}

Middle East and Central Asia Department

\section{Tunisia Monetary Policy Since the Arab Spring: The Fall of the Exchange Rate Anchor and Rise of Inflation Targeting}

\author{
Prepared by Mariam El Hamiani Khatat, Nicolas End, and Rym Kolsi ${ }^{1,2}$ \\ Authorized for distribution by Chris Geiregat
}

August 2020

IMF Working Papers describe research in progress by the authors and are published to elicit comments and to encourage debate. The views expressed in IMF Working Papers are those of the authors and do not necessarily represent the views of the IMF, its Executive Board, or IMF management.

\begin{abstract}
In this paper, we argue that inflation targeting could be the future of Tunisia's monetary policy. Monetary targeting has proven to be ineffective due to the composition of reserve money, structural liquidity deficit, and higher instability of the money multiplier after 2010. Exchange rate targeting is no longer feasible due to the level of international reserves, current account deficit, and inflation differentials with main trading partners. The Central Bank of Tunisia has already made important progress toward inflation targeting. The paper evidences the existence of increasingly effective interest rate transmission as well as the changing exchange rate passthrough to inflation with the gradual move toward further exchange rate flexibility.
\end{abstract}

JEL Classification Numbers: E4, E5, E61, F31, F32

Keywords: monetary policy framework, inflation targeting, monetary transmission, monetary operations, foreign exchange interventions, exchange rate passthrough, external shocks.

Authors' E-Mail Addresses: melhamianikhatat@imf.org; nend@,imf.org; rym.kolsi@,bct.gov.tn

\footnotetext{
${ }^{1}$ Central Bank of Tunisia.

${ }^{2}$ The authors acknowledge the valuable guidance of Taline Koranchelian and Björn Rother, and thank Chris Geiregat, Alexei Kireyev, Rima Turk, and Geneviève Verdier for their detailed comments and suggestions. The authors are also grateful to Marouane El Abassi, Governor of the Central Bank of Tunisia, as well as Moez Lajmi and the other participants of the workshop organized in May 2020 with the Central Bank of Tunisia, the Tunisian Ministry of Finance, and the Tunisian Prime Minister Office, for their comments, corrections, and feedback.
} 
Abstract

I. Introduction

II. Literature Review

III. Tunisia’s Monetary Policy History: The Legacy of the Arab Spring ............................. $\underline{9}$

A. The Fall of the Nominal Anchor and Emerging Structural Liquidity Deficit ........ $\underline{13}$

B. The Gradual Loss of Control over Monetary Aggregates ................................... 14

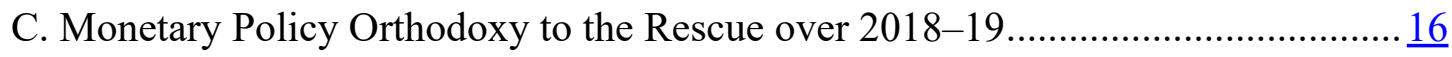

IV. Monetary Policy Transmission ........................................................................ 19

A. Monetary Transmission to Inflation and Output ............................................. 19

B. Passthrough from the Policy Rate to the Money Market Rate …......................... 22

C. Exchange Rate Passthrough to Inflation........................................................ 22

V. The Way Forward: Moving Toward Inflation Targeting ........................................... 24

A. The Case for Inflation Targeting …........................................................... 24

B. Next Steps to Support the Transition to Inflation Targeting …........................... 25

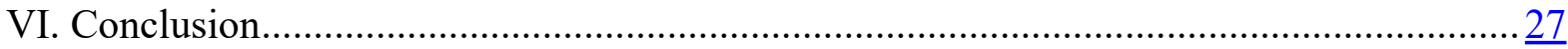

Tables

Table 1. Significance Level of the Policy Rate Coefficient .............................................. 20

\section{Figures}

1. Exchange Rates and Foreign Exchange Interventions .......................................... 10

2. Central Bank of Tunisia Balance Sheet and the Structural Liquidity Position ................... 11

3. Money, Inflation and Credit to the Private Sector....................................................... 11

4. Macroeconomic Developments and Monetary Policy Implications .............................. 12

5. Money Multiplier ........................................................................................ 13

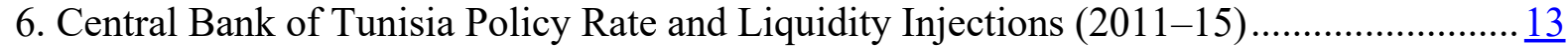

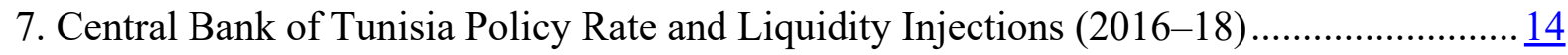

8. Central Bank of Tunisia Interest Rate Corridor, Money Market Rate, and Main

Refinancing Operations' Volume.............................................................................. 15

9. Monetary Transmission in Tunisia, 2011-17 .............................................................. 16

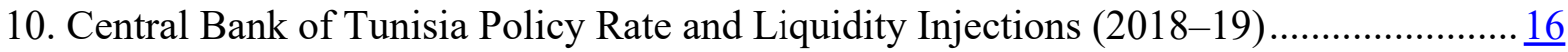

11. Tunisia Monetary-Macroprudential Policy Mix (2018-19) Simplified Transmission to Broad Money, the Exchange Rate, and Inflation ........................................................ 17

12. Reserve Money Components' Share ........................................................................... 18

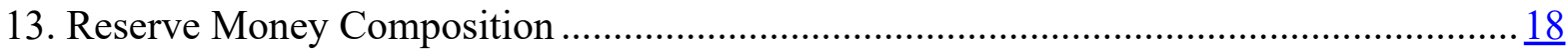


14. Currency in Circulation (Percent of the Monetary Base) ............................................ 19 15. VAR with the US Dollar Exchange Rate and the Policy Rate-Responses of Inflation and Output to a Policy Rate Shock

16. VAR with the Euro Exchange Rate and the Money Market Rate-Responses of Inflation and Output to a Money Market Rate Shock $\underline{21}$

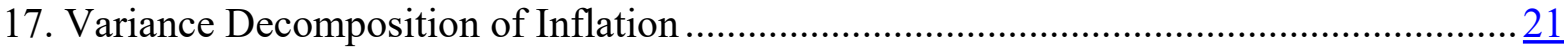

18. Variance Decomposition of Growth.................................................................. $\frac{21}{22}$

19. Central Bank of Tunisia Policy Rate and Bank Deposit and Lending Rates .................. 22

20. Dynamic Estimation of the Exchange Rate Passthrough ........................................ 23

21. Domestic Credit to the Private Sector ........................................................................ 24

22. Central Bank of Tunisia Last Published Fan Chart .................................................... 25

23. Monetary Conditionality and the Evolving Monetary Policy Framework in Tunisia....... 27

\section{Appendixes}

I. Central Bank of Tunisia Simplified Balance Sheet and the Structural Liquidity

Position of the Banking Sector

II. VAR Impulse Responses, Variance Decomposition, and Exchange Rate

Passthrough Estimation Results $\underline{29}$

III. Definition of Monetary Policy Frameworks and Anchors ........................................ $\underline{33}$

IV. Primacy of Price Stability Versus Multiple Monetary Objectives ............................... $\underline{35}$

V. Tunisia Financial Development - Comparison to Peers ........................................... $\underline{36}$

VI. Selected Countries' Monetary Policy/Inflation Reports-Main Content......................... $\underline{37}$

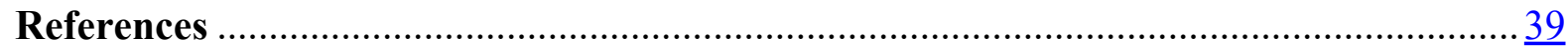




\section{GLOSSARY}

$\begin{array}{ll}\text { AREAER } & \text { Annual Report of Exchange Arrangements and Exchange Restrictions } \\ \text { CBT } & \text { Central Bank of Tunisia } \\ \text { CIC } & \text { Currency in Circulation } \\ \text { CPI } & \text { Consumer Price Index } \\ \text { DIA } & \text { Devises des Intermédiaires Agréés } \\ \text { EFF } & \text { Extended Fund Facility } \\ \text { EOP } & \text { End of Period } \\ \text { EUR } & \text { Euro } \\ \text { FX } & \text { Foreign Exchange } \\ \text { GDP } & \text { Gross Domestic Product } \\ \text { IMF } & \text { International Monetary Fund } \\ \text { IT } & \text { Inflation Targeting } \\ \text { LTD } & \text { Loan-to-Deposit } \\ \text { MMD } & \text { Marché Monétaire en Devise } \\ \text { MMR } & \text { Money Market Rate } \\ \text { MRO } & \text { Main Refinancing Operation } \\ \text { MT } & \text { Monetary Targeting } \\ \text { NDA } & \text { Net Domestic Assets } \\ \text { NEER } & \text { Nominal Effective Exchange Rate } \\ \text { NFA } & \text { Net Foreign Assets } \\ \text { O/N } & \text { Overnight } \\ \text { QPM } & \text { Quarterly Projection Model } \\ \text { REER } & \text { Real Effective Exchange Rate } \\ \text { SBA } & \text { Stand-by Arrangement } \\ \text { TND } & \text { Tunisian Dinar } \\ \text { USD } & \text { United States Dollar } \\ \text { VAR } & \text { Vector Autoregression }\end{array}$




\section{INTRODUCTION}

Before 2011, Tunisia operated an exchange rate anchor under which reserve money growth was mostly driven by the accumulation of Net Foreign Assets (NFA). Supported by fiscal discipline, the growth of NFA maintained the banking system in structural liquidity surplus and limited the need for liquidity injections by the Central Bank of Tunisia (CBT). In the wake of the Revolution, the trend accumulation of NFA reverted and the composition of the central bank's assets changed in favor of growing Net Domestic Assets (NDA) that offset the losses of NFA. The monetary base remained stable until 2015. After the 2015 terrorist attacks, however, the CBT's balance sheet started to expand steadily due to the accelerating demand for cash and foreign currency that was accommodated by a substantial scaling-up of central bank refinancing operations. The balance sheet expansion fueled the growth of broad money and ultimately inflation that peaked in June 2018 at 7.7 percent.

Monetary tightening started in 2017 and contained inflation from July 2018. The CBT first increased its policy rate in April 2017, but its growing liquidity injections continued to pursue the objective of easing the credit supply. Negative real interest rates, an increasing volume of refinancing, and the collateral policy accommodated the money demand of economic agents and especially the demand for cash and foreign currency fueled by depreciation expectations. A clear change in the CBT's monetary and macroprudential policies occurred in 2018: the policy rate was increased in gradual steps from 5 percent in early 2018 to 7.75 percent in February 2019, slowing the demand for credit. In addition, macroprudential policy was tightened at the end of 2018 and constrained the supply of credit.

Clarifying the monetary policy framework is critical to achieve further disinflation. Monetary targeting has proven to be ineffective as reserve money is mainly composed of currency in circulation (CIC) and bank accounts in foreign currency. Moreover, due to the volatility of money demand, the money multiplier has become less stable after 2010. Exchange rate targeting is no longer feasible due to the level of foreign exchange (FX) reserves, current account deficit, and inflation differentials with main trading partners. The CBT has already made important progress toward inflation targeting (IT) through the implementation of an interest rate mid-corridor system, the development of macro-forecasting models, and introduction of FX auctions. Additional efforts could focus on strengthening central bank governance and interest rate transmission, improving communication, and upgrading the central bank's analytical and forecasting capacity.

This paper presents a retrospective of Tunisia's monetary policy since the Arab Spring. It extracts the main lessons learned from the design and implementation of monetary policy during the last decade to build a better future for the CBT's monetary policy. Tunisia is an interesting case of an emerging market economy that decided to abandon the exchange rate anchor and transition toward an IT regime. While the transition is not over yet, we document how the transmission channels promisingly start to operate better.

The rest of the paper is structured as follows. Section II reviews the main relevant literature on the choice and evolution of monetary policy frameworks, transition to IT, and monetary transmission. Section III explains the history of Tunisia's monetary policy since the Arab Spring. It breaks down the 2010s decade into three subperiods, during which the CBT's monetary policy has progressively evolved. Section IV discusses how the interest rate 
channel and exchange rate passthrough to inflation evolved over time. Section $\mathrm{V}$ describes the progress made by the CBT toward IT and further steps to be considered during the transition. Section VI concludes.

\section{LITERATURE REVIEW}

This paper builds on three strands of literature. It draws from the literature on the optimal choice of a nominal anchor and evolution of monetary policy frameworks to better explain Tunisia's inflation developments after the exchange rate anchor was abandoned. Relevant for the current paper include the topics of the choice of monetary policy framework, the transition to inflation targeting, and monetary transmission. We summarize the main contribution to this literature below.

\section{Choice and Evolution of Monetary Policy Frameworks}

Following Mundell (1961), the optimal choice of an exchange rate arrangement depends on the nature of shocks - whether real or nominal - and the degree of capital mobility. In an open economy with capital mobility, the floating exchange rate insulates against real shocks (for example, terms-of-trade shocks), while a fixed exchange rate can be adopted in case of nominal shocks. The criteria suggested by Mundell (1961), McKinnon (1963), and Kenen (1969) to assess the choice of the exchange rate as a nominal anchor include the symmetry of shocks, trade linkages, the degree of openness, and the degree of factor mobility. Other macroeconomic criteria relevant to the choice of monetary policy anchor include the level of inflation, the level of FX reserves, as well as fiscal policy flexibility and sustainability (Eichengreen and others 1998).

A distinct set of criteria underlying the choice of a monetary policy framework is related to the importance of a credible nominal anchor. Credibly committing to low inflation policies may be challenging and costly in the absence of a strong institutional track record, sound liquidity management, modeling and forecasting capabilities, and a stable financial system supporting interest rate transmission. Therefore, countries may also consider policy criteria rather than macroeconomic ones in their choice of an exchange rate arrangement. They may adopt pegs even when many of the macroeconomic criteria fail to apply, and when they choose to borrow the monetary policy credibility of another country or when the institutional capacity to implement flexible exchange rate regimes is still undeveloped (Levy-Yeyati and Struzenegger 2010, and E1 Hamiani Khatat and Veyrune 2019).

In his seminal paper "Monetary Policy Strategy: How Did We Get There?”, Mishkin (2006) describes how the monetary policy thinking has evolved over time. The author evidences the six key principles that are largely accepted by monetary authorities and governments in many countries and that have contributed to improved monetary performance: (1) there is no long-run tradeoff between output (employment) and inflation; (2) expectations are critical to monetary policy outcomes; (3) inflation has high costs; (4) monetary policy is subject to the timeinconsistency problem; (5) central bank independence helps improve the efficacy of monetary policy; and (6) a strong nominal anchor is the key to producing good monetary policy outcomes.

The literature also reveals that the popularity and effectiveness of monetary targeting has declined over time. In many countries, velocity and money multipliers have been subject to frequent and large fluctuations that have complicated the conduct of monetary policy. Indeed, financial 
development tended to reduce the stability of money demand and the money multiplier. At the same time, financial market liberalization has expanded the scope for an active management of money market rates, while lower levels of inflation, frequent and large exogenous shocks, and increasing instability in money demand have reduced the relevance of traditional monetary targeting frameworks. As a result, many central banks of developing countries are adopting more flexible and forward-looking monetary policy frameworks with a greater role of policy interest rates and inflation objectives. Several emerging and developing countries that were forced off pegs after sudden reversals of capital inflows have also introduced hybrid frameworks, with an increasingly significant role for inflation (IMF 2014).

\section{Transition to Inflation Targeting}

The early literature on the transition to IT assessed the scope for this type of monetary policy framework in developing countries (Masson, Savastano and Sharma 1997). It identified the key prerequisites for the successful adoption of IT as the ability to conduct an independent monetary policy - free from fiscal dominance or commitment to another nominal anchor such as the exchange rate - and a quantitative framework linking policy instruments to inflation. Carare and others (2002) provide advices on establishing the initial conditions in support of IT. These conditions include: a mandate in support of an inflation objective and accountability for achieving this objective; macroeconomic stability; a sufficiently welldeveloped and stable financial system; and effective implementation tools.

Stone (2003) assesses transitional monetary policy frameworks, such as inflation targeting lite (ITL). Freedman and Ötker-Robe (2009) present some country experiences with the introduction and implementation of IT, and Freedman and Ötker-Robe (2010) important elements for IT for emerging economies. The authors examine whether certain conditions have to be met before emerging economies can adopt IT. The issues analyzed are the priority of IT over other goals, the absence of fiscal dominance, central bank independence, the degree of control over the policy interest rate, a sound methodology for forecasting, the soundness of financial institutions and markets, and resilience to changes in exchange rates and interest rates.

More recent papers stress the need for transitional arrangements when considering the move to IT. IMF (2015) addresses the case of countries that have regimes without an explicit commitment to a fixed exchange rate and with some degree of exchange rate flexibility, as the majority of low-and lower-middle income countries follows monetary targeting regimes. Laurens and others (2015) also focus on transitional arrangements for countries moving from monetary targeting to IT.

\section{Monetary Transmission}

In standard macroeconomic models, the interest rate channel is the main channel of monetary transmission. These models emphasize the effects of monetary policy on the real interest rateunder the assumption of wage and price stickiness - on the cost of capital, and aggregate demand. The policy rate being a short-term interest rate, effective monetary policy transmission also involves the link between the short-term and long-term interest rates, and the existence of a term structure of interest rates: expectations operating on the term structure tie long-term to short-term interest rates (Boivin and others 2010, and Mishra and others 2012). As this paper focuses on 
interest rate transmission and exchange rate passthrough, we mainly review the relevant empirical literature for this.

The empirical literature usually assesses interest rate transmission with Vector Autoregression (VARs) and Error Correction Models (ECMs), as well as simple regressions. It tends to split interest rate transmission into different steps: a first step assessing the transmission of monetary policy shocks to output and inflation; and another investigating the passthrough of the policy rate to money market rates and bank deposit and lending rates.

Bernanke and Blinder (1992) showed that the federal funds rate was highly informative about future movements of real macroeconomic variables and markedly superior to both monetary aggregates and most other interest rates as a forecaster of the economy. Christiano and others (1996) assessed the transmission of Federal Reserve monetary policy shocks using VARs including real GDP, GDP deflator, an index of commodity prices, nonborrowed reserves, the federal funds rate, and total reserves. The authors included a measure of commodity prices to avoid the price puzzle. ${ }^{1}$ A relatively similar ordering of the variables was adopted for the specification of the VAR in Christiano and others (2005).

The empirical literature tends to report differences across countries in the strength of interest rate passthrough from the policy rate to money market and bank retail rates. The effectiveness of monetary transmission depends on the structure of the financial sector and more specifically: the degree of banks' monopoly/competition and ownership of the banking system; the volatility of money market rates; capital mobility, and availability of foreign sources of finance (Cottarelli and Kourelis 1994, Borio and Fritz 1995, Mojon 2000, Donnay and Degryse 2001, Toolsema and others 2002, and de Bondt 2002). Lending rates generally adjust faster in more sophisticated financial systems. However, recent research has found that having a modern monetary policy framework - adopting IT and independent and transparent central bank - matters for monetary transmission, possibly more than financial development (Brandao-Marques and others 2020).

This paper contributes to the existing literature with two main findings: (1) it evidences the changing interest rate transmission and exchange rate passthrough with the move to further exchange rate flexibility; (2) it adds the composition of reserve money and structural liquidity position of the banking system to the list of criteria that are important for the choice of nominal anchor.

\section{Tunisia’s Monetary Policy History: The Legacy Of THE ARAB Spring}

Monetary and FX policies before 2010 underpinned a steady buildup of NFA. Supported by FX inflows, the CBT's NFA increased by an annual average of 20 percent over 2001-10. This assured base money and broad money growth of an average of 13 and 11 percent over the same period, respectively. Also helped by fiscal discipline, inflation was contained at an average of 3.4 percent. The banking sector was in a structural liquidity surplus over the period 2007-10, and bank reserves in Tunisian Dinar (TND) provided a buffer against negative liquidity shocks induced by fluctuations in autonomous liquidity factors.

\footnotetext{
${ }^{1}$ The Price Puzzle is the result that a contractionary shock to monetary policy is associated with an initial rise in the price level. According to Sims (1992) such an outcome reflects the fact that the central bank faces exogenous sources of inflation that are missing from the VAR used to estimate policy shocks.
} 
The Arab Spring led to a fundamental change in monetary conditions and policies. Large FX outflows occurred immediately after the Revolution and a continuous reduction of NFA became a continuous feature of post-Revolution monetary surveys. The CBT first leaned against the dinar depreciation with growing FX interventions sterilized through domestic liquidity injections (Figure 1). Then, under the impression of the 2015 terrorist attacks, the authorities' desire to protect credit growth through stepped-up liquidity injections undermined their efforts to mitigate rising price pressures through an interest rate response. Inflation was addressed effectively only in 2018 through the combined effort of more forceful policy rate hikes and a tightening of macroprudential regulation.

The post-2010 monetary history followed three distinct phases: (1) the move to further exchange rate flexibility in the aftermath of the Arab Spring and the emergence of banks' structural liquidity deficit; (2) the growing volume of central bank refinancing after the 2015 terrorist attacks that led to a loss of control over monetary aggregates and rendered ineffective the initial attempts to contain inflation through policy rate hikes; and (3) the more forceful policy tightening since 2018 to counter accelerating inflation.

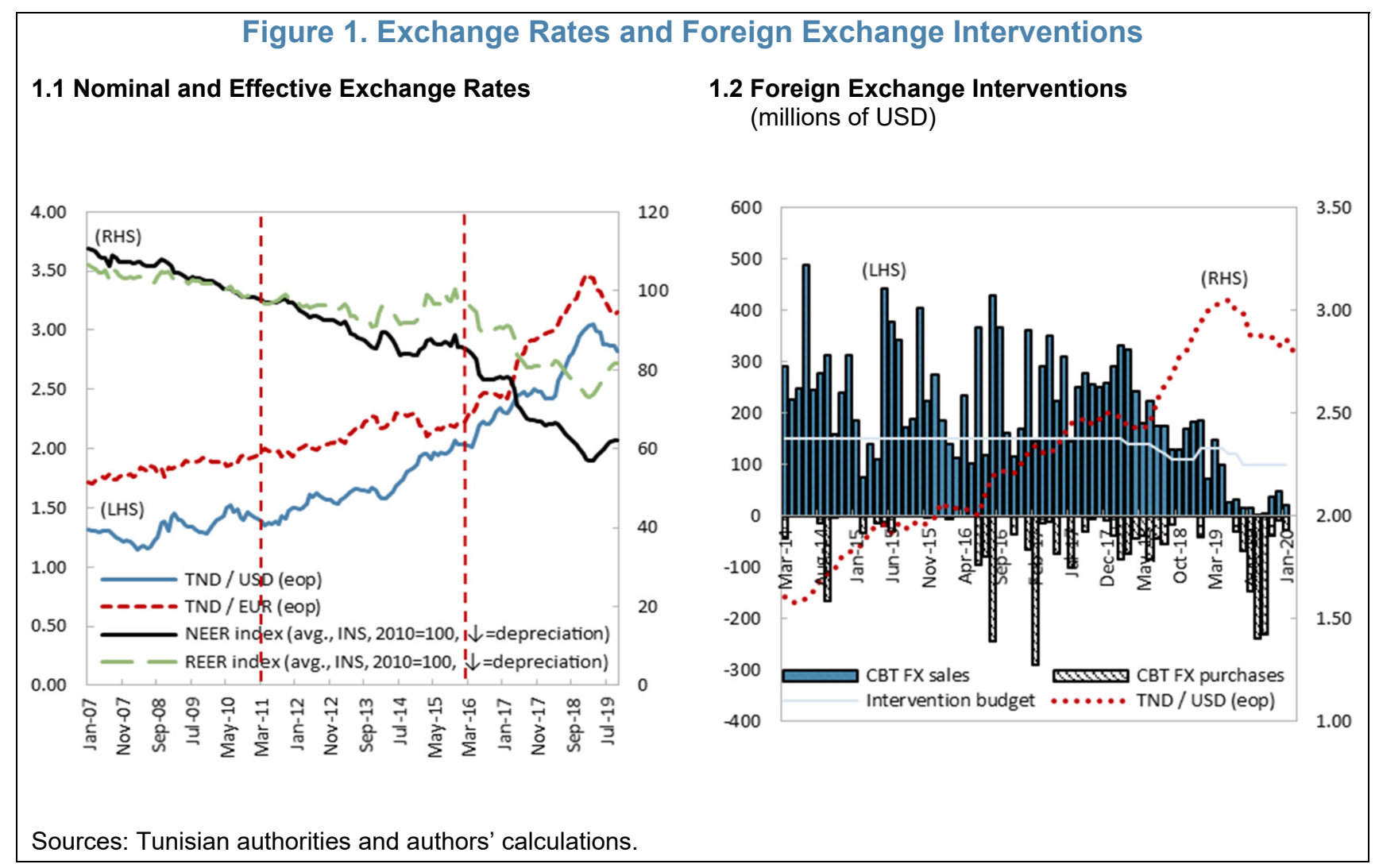


Figure 2. Central Bank of Tunisia Balance Sheet and the Structural Liquidity Position

2.1 Central Bank of Tunisia Analytical Balance Sheet (Billions of TND)

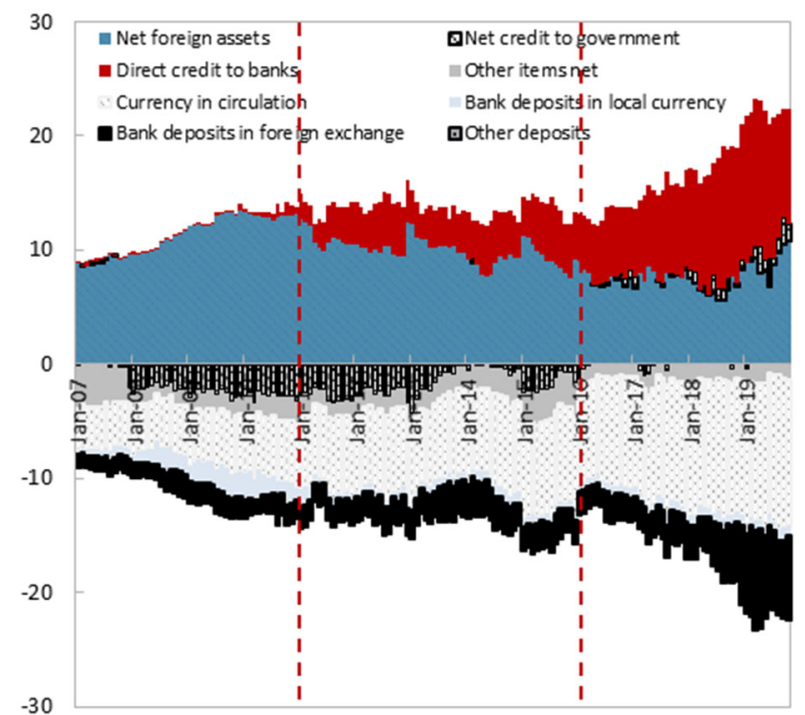

2.2 Structural Liquidity Position of the Tunisian Banking Sector (Billions of TND)

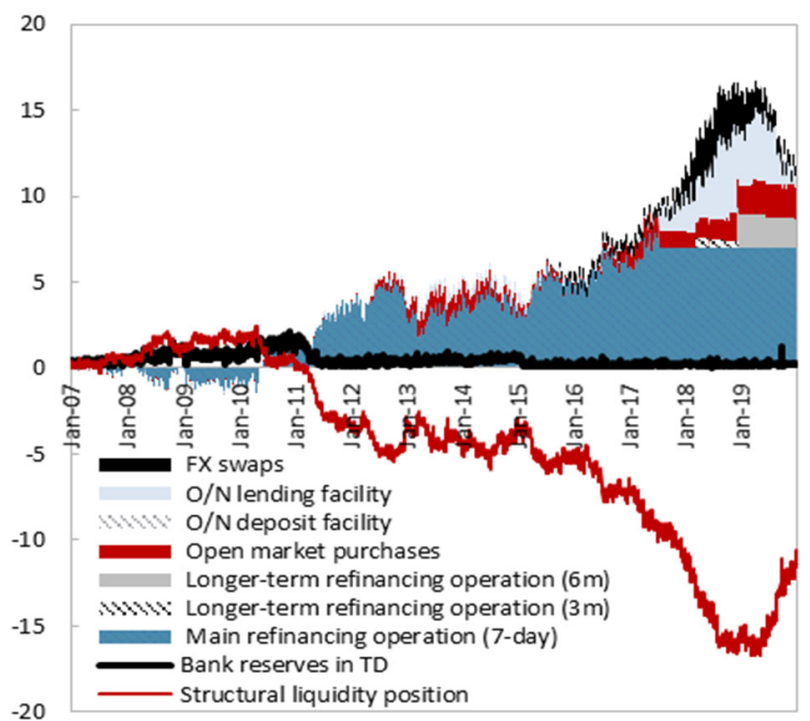

Sources: Central Bank of Tunisia and authors' calculations.

\section{Figure 3. Money, Inflation and Credit to the Private Sector}

3.1 Inflation, Broad Money, and Credit Growth

(Percent, year-on-year)

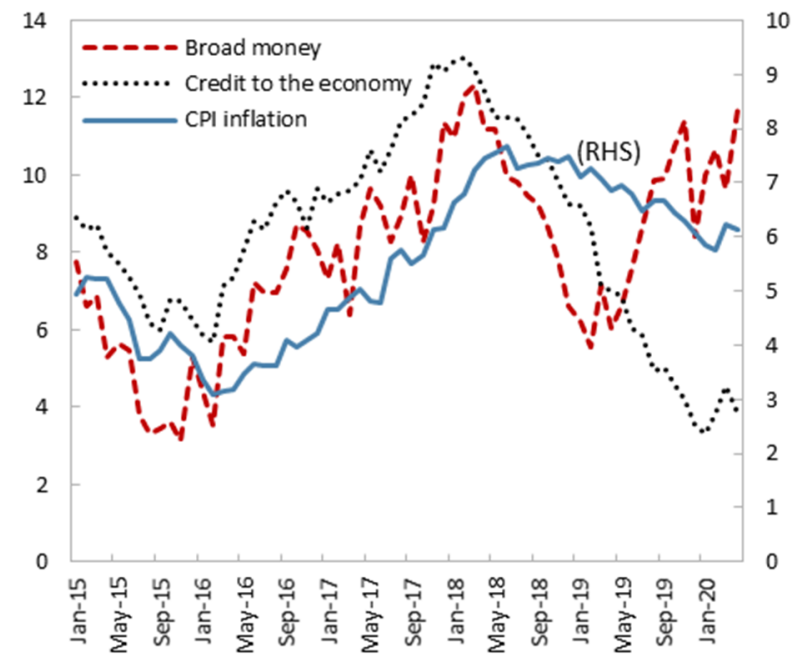

3.2 Inflation, Policy Rate, and Exchange Rates (Percent, year-on-year)

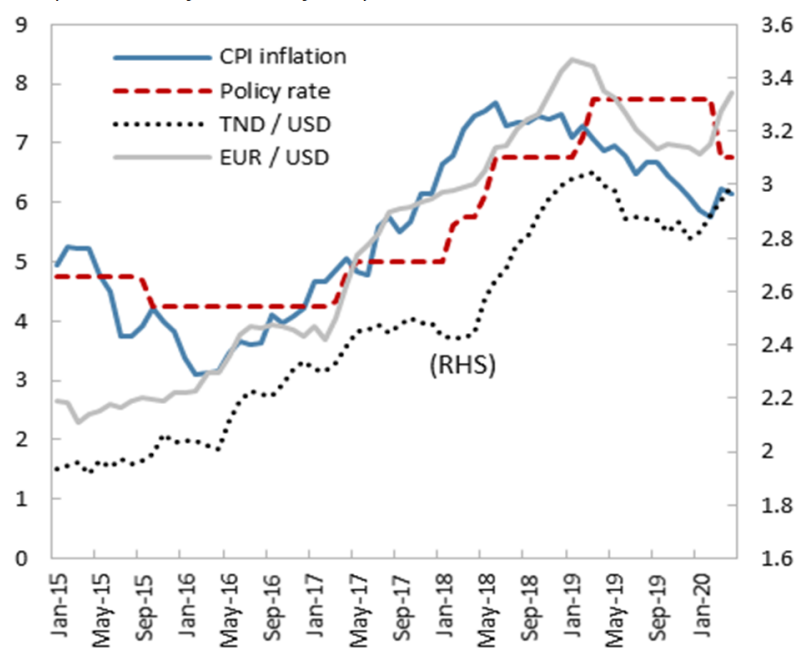

Sources: Tunisian authorities and authors' calculations. 


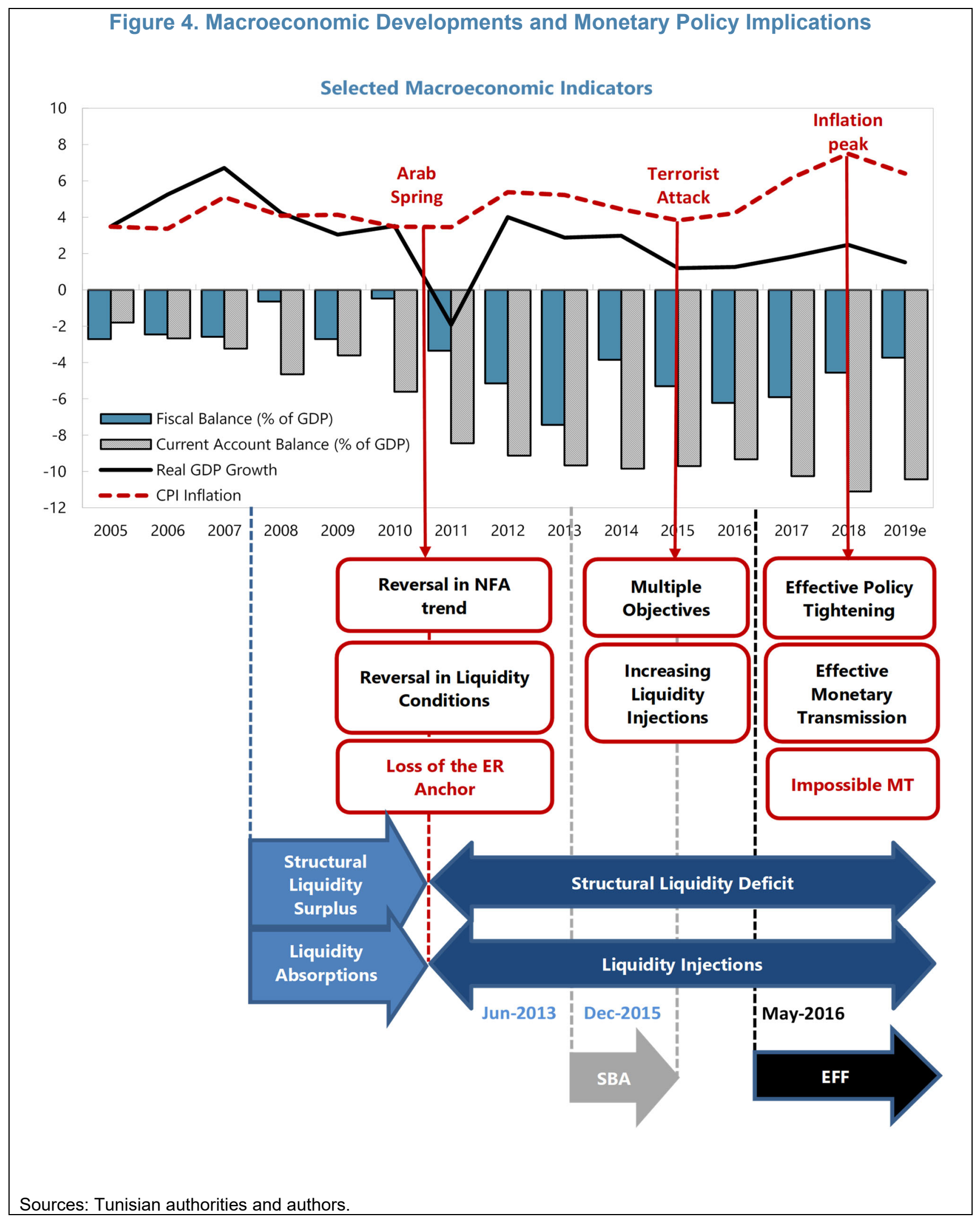

CInternational Monetary Fund. Not for Redistribution 


\section{A. The Fall of the Nominal Anchor and Emerging Structural Liquidity Deficit}

Prior to the Revolution, the CBT anchored the dinar to a basket of main trading partners' currencies. The exchange rate was de jure floating, but the regime was de facto classified as a stabilized arrangement. ${ }^{2}$ In 2011 , the reversal in FX flows and less stable money multiplier led the CBT to move gradually toward greater exchange rate flexibility (Figure 5). This resulted in a de facto classification of the exchange rate arrangement as floating in 2016. The classification switched again to a crawl-like arrangement in May 2017 (IMF 2018).

The structural liquidity position of the banking system, that was positive until 2010, turned negative in 2011 (Figures 2.2). The reversal occurred as a result of FX outflows and FX interventions. Consequently, the CBT reduced the reserve requirement ratio from 12.5 to 2 percent in May 2011, and then to 1 percent in late 2013.

Monetary policy responded to these challenges but without a clear nominal anchor. This led to the AREAER's classification of the monetary policy framework under "other" since 2011. On the one hand, rising inflation propelled the CBT to increase its policy rate several times to a maximum of 4.75 percent in June 2014 (Figure 6). ${ }^{3}$ At the same time, the CBT responded to commercial banks' growing needs for dinar liquidity through refinancing operations that kept the size of the central bank balance sheet broadly stable (Figure 2): the total volume of these liquidity injections, mainly through the 7-day Main Refinancing Operations (MROs), grew from an average of TND 1.6 billion in January 2011 to TND 4.3 billion in mid-February 2012, de facto sterilizing the FX sales that the CBT undertook in defense of the dinar.

\footnotetext{
${ }^{2}$ Source: Annual Report on Exchange Arrangements and Exchange Restrictions (AREAER; IMF 2011).

${ }^{3}$ Earlier, the CBT decreased its policy rate from 4.5 percent in end-2010 to 3.5 percent in September 2011.
} 


\section{B. The Gradual Loss of Control Over Monetary Aggregates}

Between 2016 and mid-2018, Tunisia experienced strong monetary expansion. The CBT's balance sheet started to expand rapidly after the 2015 terrorist attacks. This trend was driven by increasing NDA that reflected a growing volume of central bank liquidity injections on the asset side to support credit growth during the economic slowdown and accommodate the demand for cash and FX. The total volume of the CBT's refinancing increased by 60 percent between July 2017 and July 2018 before stabilizing in August 2018 (Figures 2 and 7).

The NDA expansion combined with exchange rate passthrough to fuel inflation. Figure 3 shows the almost parallel movement of credit to the economy, broad money, the dinar exchange rate vis-à-vis the Euro and the US dollar, and CPI inflation with the

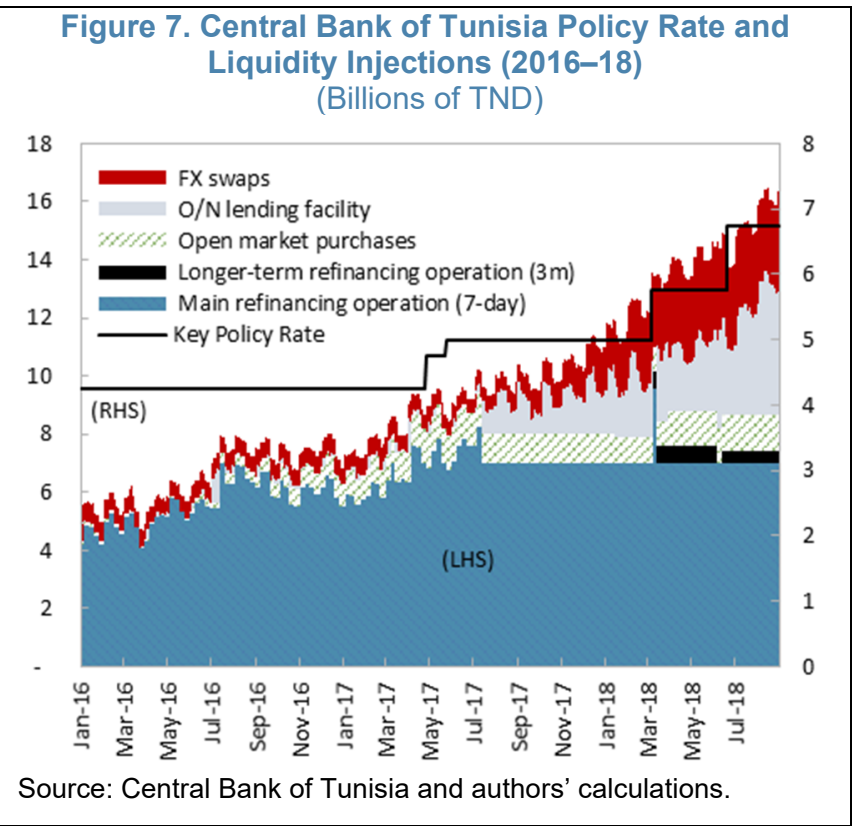

Source: Central Bank of Tunisia and authors' calculations. expansion of the central bank's balance sheet. Exchange rate developments during this period were partly the result of accommodative monetary conditions and depreciation expectations fueled by a public announcement on the exchange rate. This led to an increase in FX accounts held at the central bank, whose share in reserve money almost doubled from 18 percent in 2011 to 35 percent in 2018. Estimations of the exchange rate passthrough while controlling for other variables indicate a significantly positive long-term effect of about 25-30 percent, even in the presence of many regulated prices for imported goods such as energy and food.

Multiple objectives undermined the effectiveness of the monetary tightening. ${ }^{4}$ Price stability became the CBT's main objective in $2016 .{ }^{5}$ Consistent with this focus, the CBT started to increase its policy rate by 50 basis points in April 2017 from a low 4.25 percent maintained since October 2015, and again by 25 basis points in May. At the same time, however, the central bank continued to increase the volume of its refinancing operations, thereby counteracting the tightening objective. De facto, monetary policy targeted inconsistent objectives: price stability on the one hand, and desirable levels of credit and financial sector stability on the other. Inflation was strongly influenced by broad money and the exchange rate over 2016-17, with the growth of money aggregates interfering with the interest rate channel (Figure 9).

\footnotetext{
${ }^{4}$ Monetary policy is one policy instrument that cannot be expected to deliver on multiple inconsistent objectives, and monetary policy is ultimately limited in its ability to directly influence real variables in the long-term and is instead most effective in providing a nominal anchor (IMF, 2015).

${ }^{5}$ Law No. 2016-35 of April 25, 2016 fixing the Statute of the Central Bank of Tunisia that reinforced the price stability objective as the main objective of the CBT (article 7) and strengthened central bank independence. The price stability objective was also enshrined in the statutes of the Central Bank of 2006 (Article 33).
} 
Distortions have continued to alter the monetary transmission mechanism. These include the cap on lending rates and the decision of commercial banks to shield certain categories of loans such as existing household mortgages from interest rate adjustments. Monetary policy implementation was further complicated by the cap on the outstanding volume of the 7-day MRO, introduced in July 2017. The cap weakened the passthrough from the policy rate to the money market rate (MMR), widening the spread between the MMR and the policy rate that only narrowed substantially after the last policy rate increase in March 2019 (Figure 8). ${ }^{6}$ In addition, the cap pushed the refinancing into instruments other than the MRO: after the introduction of the cap, a large share of the refinancing volume moved to the overnight $(\mathrm{O} / \mathrm{N})$ lending facility. The $\mathrm{CBT}$ also increased substantially the volume of TND liquidity injections through FX swaps (Figure 7).

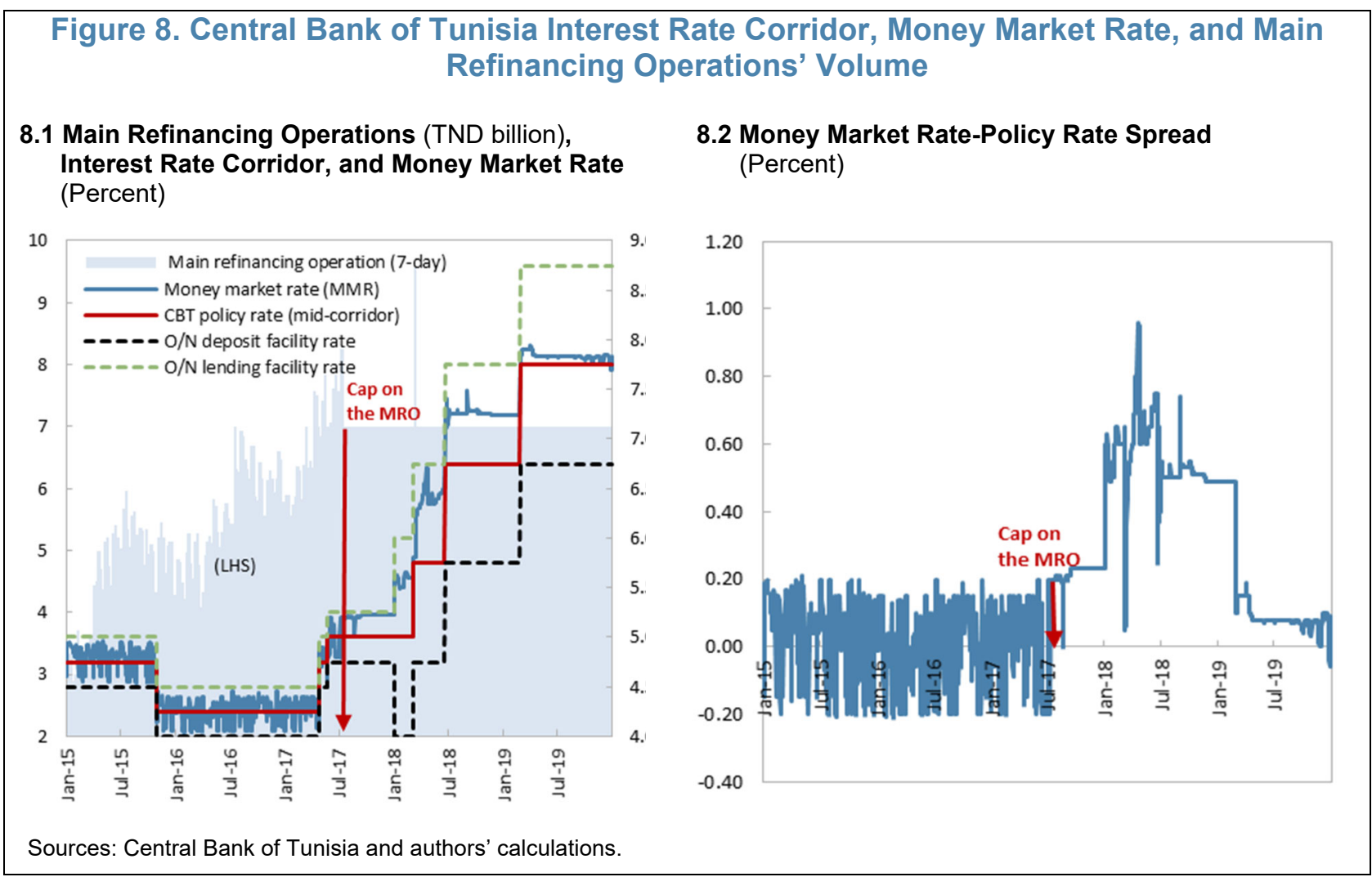

\footnotetext{
${ }^{6}$ The spread increased from an average 10 basis points over January 2015 to July 2017 to an average 41 basis points after July 2017.
} 


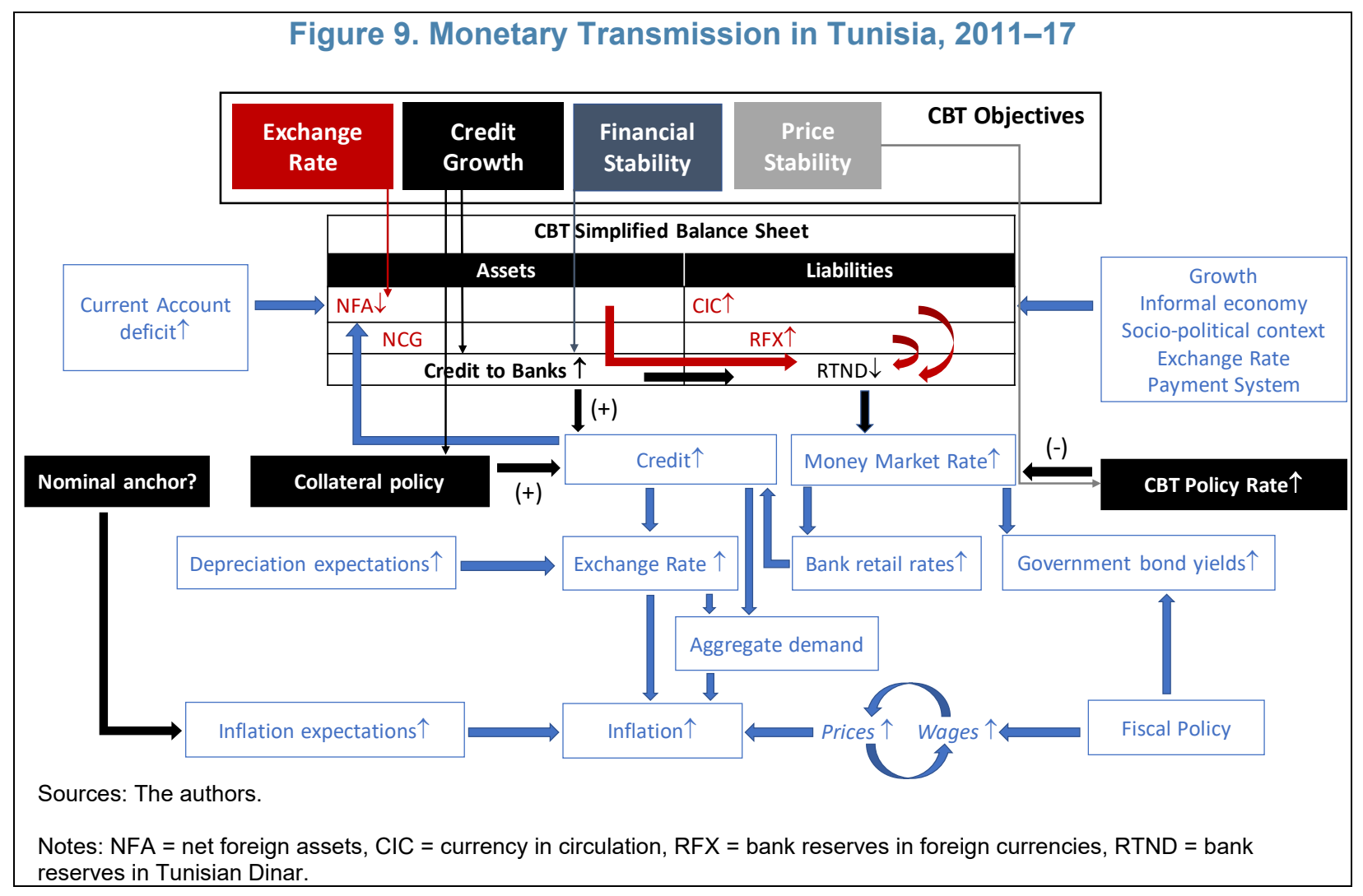

\section{Monetary Policy Orthodoxy to the Rescue over 2018-19}

A rising inflation threat finally led the CBT to tighten monetary policy more forcefully. Monetary policy tightening was effective starting 2018 , when the CBT increased its policy rate sufficiently to make it positive in real terms, while at the same time containing the volume of its refinancing operations. The reduction of the refinancing volume was mainly the result of the tightening of the Loan-to-Deposit (LTD) ratio. With the policy tightening and the shift of market expectations from depreciation to appreciation, the central bank started buying FX against TND. The latter has also contributed to lower volumes of refinancing (Figures 2 and 10).

Early results of the CBT's policy actions undertaken in 2018-19 point to more effective policy actions. Figure 11 explains the transmission of the CBT's monetary and

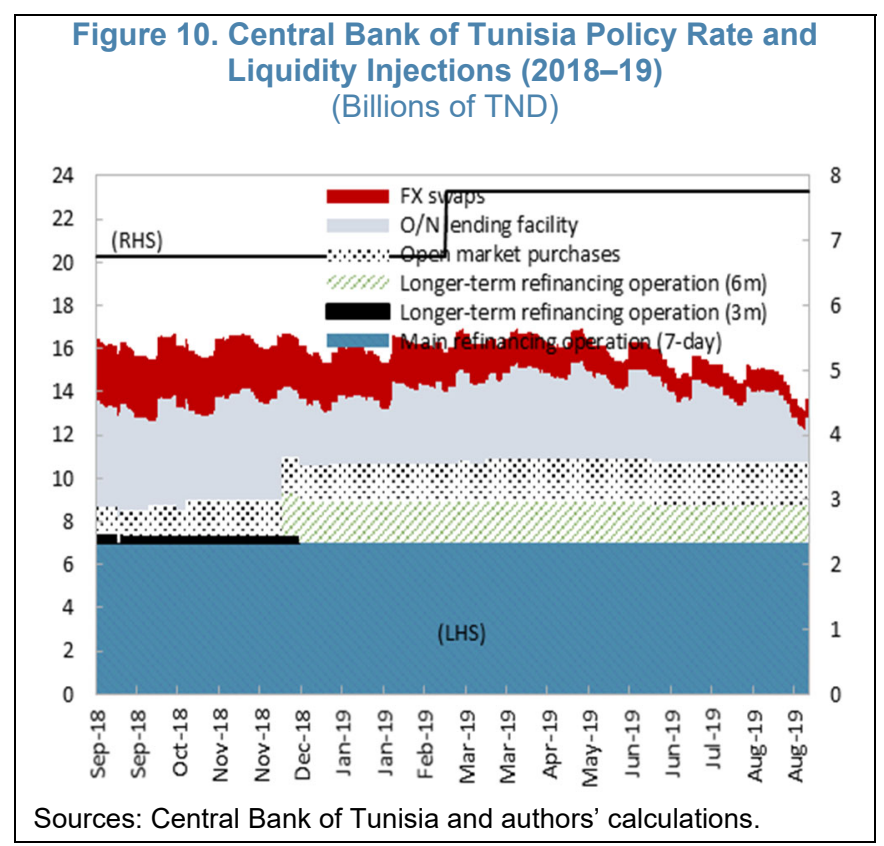
macro-prudential policies to inflation through the channels of broad money and credit: broad money growth halved from its 2017 levels by mid-2018, while the growth of credit to the economy decreased from 12.7 percent in 2017 to 8 percent in 2018 and 4.9 percent in August 2019 
(Figure 3). As a result of more effective policy tightening, inflation declined from its peak of 7.7 percent in June 2018 to 5.8 percent in February 2020. Following the decrease of the policy rate by a 100 basis points in March 2020 in reaction to the Covid-19 shock, inflation increased again to 6.2 percent in March 2020. However, given the transmission delays of monetary policy that take 6 to 8 quarters to affect inflation, the resurgence of inflationary pressures are more likely the result of supply shocks affecting food prices as well as the extension of maturities of loans to households (increasing their purchasing power by about 40 percent).

At the same time, reserve money targeting has been difficult to implement. Bank reserves in dinar only represent a small fraction of reserve money: in August 2019, out of a total of TND 20.9 billion, CIC represented TND 14.1 billion (68 percent) and bank reserves in FX, TND 6.5 billion (31 percent). Bank reserves in dinar only amounted to TND 0.3 billion ( 1 percent). While the CIC has always represented the largest share of reserve money, bank accounts in TND remained at very low levels since 2011 while bank accounts in FX (DIA and MMD) rose over time (Figures 12 and 13). This implies that a reduction of reserve money would have to rely mostly on shrinking CIC and/or bank accounts in FX, which however is difficult to achieve: CIC in Tunisia as in many other countries has a positive trend (it remained positive despite the five policy rate hikes for a total of 350 basis points in 2017-19); and FX account balances are mostly driven by balance of payment developments and market expectations of the exchange rate. The low level of bank reserves in TND reduces their capacity to absorb negative liquidity shocks, for example a tax payment or a bond issuance, or a holiday-induced increase in the demand for cash. In the absence of the CBT's liquidity injections, such shocks would push bank reserves in dinar into negative territory.

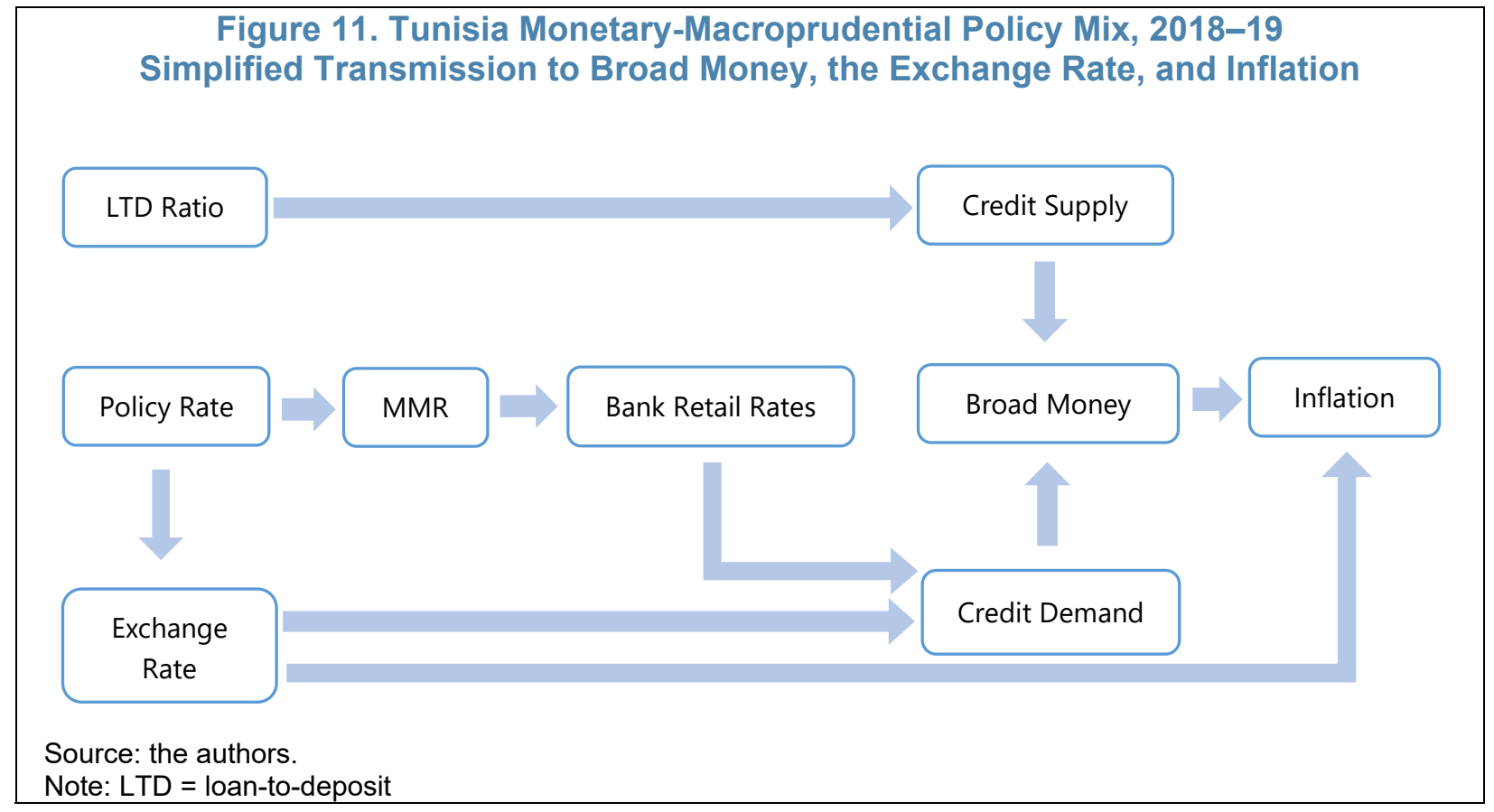


Tunisia shares the issue of large CIC with other emerging markets and peer countries. Algeria, Indonesia, Malaysia, Morocco, Russia, and Ukraine (Figure 14) have even higher shares of CIC in base money. In response to this challenge, the Tunisian authorities launched a de-cashing action plan in March 2018, which aims at limiting cash payments by the public administration and at adopting a regulatory framework for electronic payments. The de-cashing strategy is an important component of the authorities' efforts to fight the informal economy, ease liquidity pressures, and modernize the payment systems by moving toward innovative payments services (such as online and mobile payments).

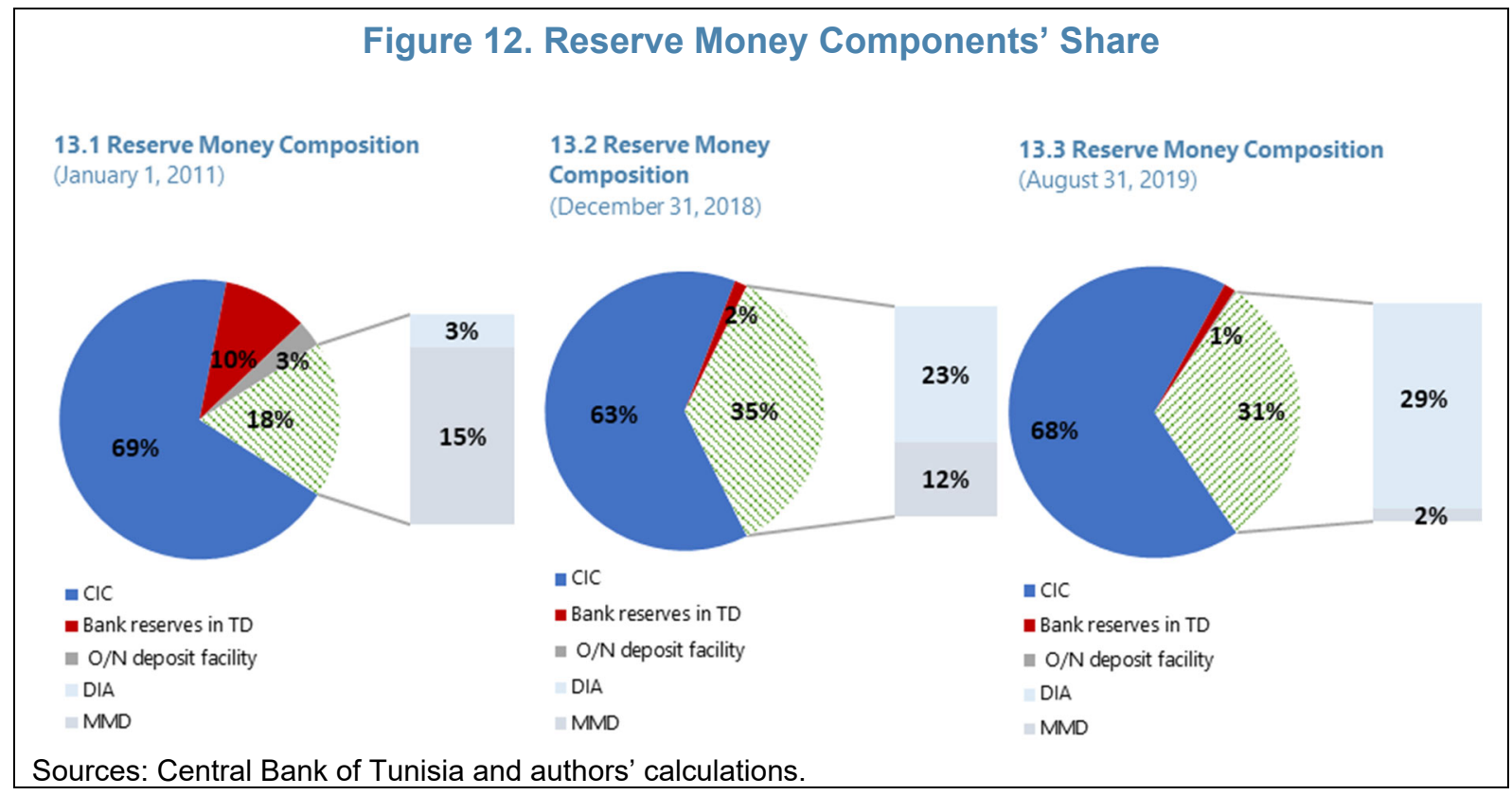

Figure 13. Reserve Money Composition 13.1 Reserve Money Components (2007-2019)
(Billions of TND)

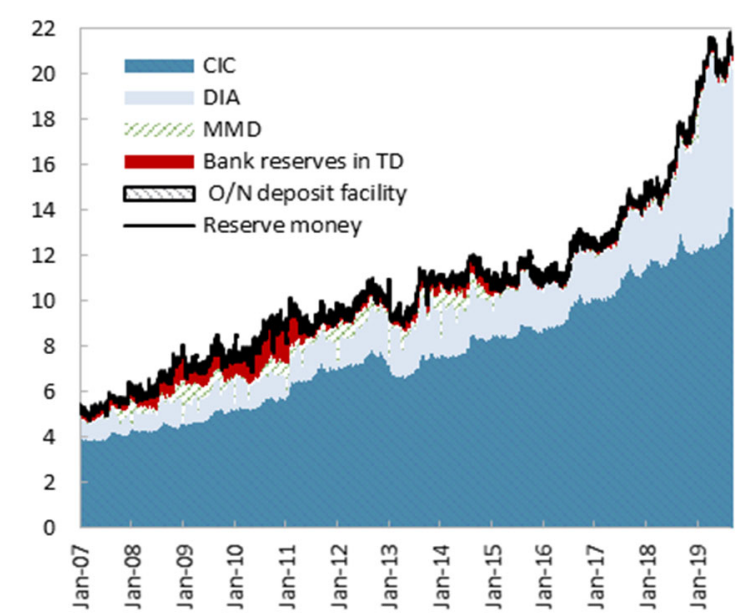

13.2 Bank Reserves in TND and FX (DIA \& MMD) (Billions of TND)

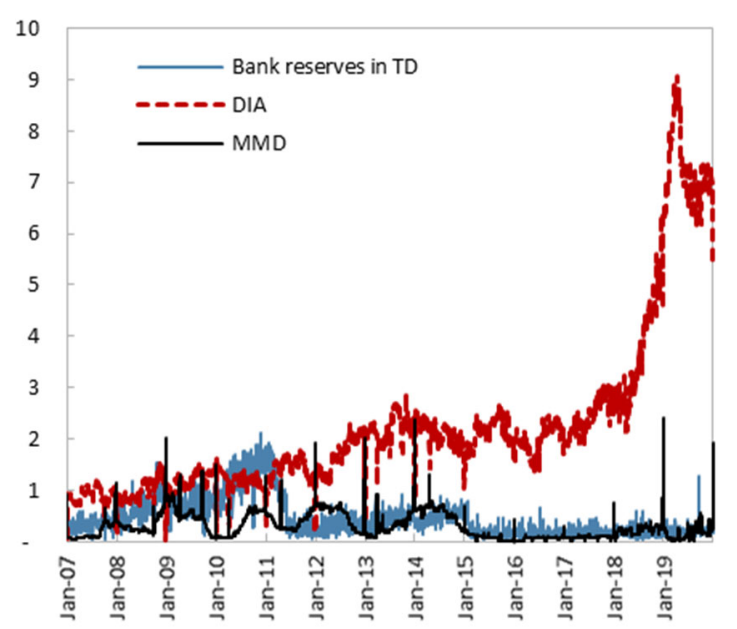

Sources: Central Bank of Tunisia, and authors' calculations.

Note: DIA accounts (for "Devises des intermédiaires agréés") are bank accounts in FX at the BCT; MMD accounts ("Marché monétaire en devises") represent the share of DIA that is invested by CBT for maturities over 7 days. 


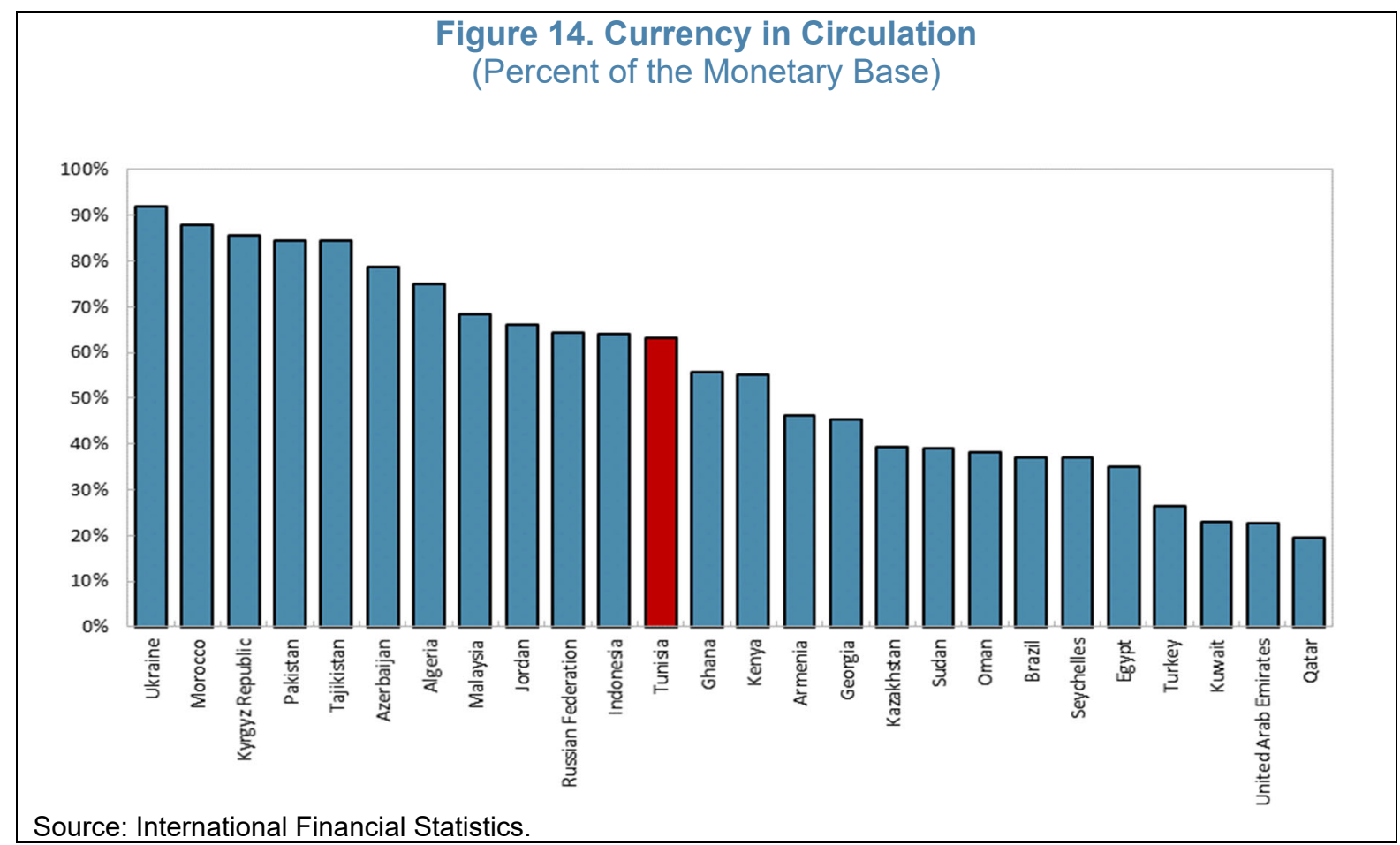

\section{Monetary Policy Transmission}

The CBT has recently proven its capacity to implement a pro-active interest rate-based monetary policy: the 275 basis points hike of the policy rate since early 2018, as well as the tightening of macroprudential policy, produced a significant slowdown of broad money, credit to the economy, and ultimately inflation. As the policy tightening since 2018 started demonstrating its effectiveness, we investigate how strong the transmission mechanism is in Tunisia, and whether it has changed over time. To do this, we adopt a two stage approach as identified in the empirical literature on interest rate transmission: (1) we first assess the transmission of monetary policy shocks to output and inflation; and then (2) discuss the passthrough of the policy rate to the MMR and bank retail rates. We then analyze and discuss how has the exchange rate passthrough evolved over time, with greater exchange rate flexibility since 2011.

\section{A. Monetary Transmission to Inflation and Output}

To assess monetary transmission, we estimate VAR models over 2010Q1-2019Q3, broadly following the methodology used by Christiano and others (2005) for the ordering of the variables. The variables included in the first VAR are real GDP growth (GR), inflation (PI), the bilateral exchange rate to the US dollar (USDTND), the CBT's policy rate (BCT_RATE), and broad money (M3) growth. We also include the oil price as exogeneous variable. The generated impulseresponse functions with a Cholesky decomposition are presented in Figure 15 and Appendix II.

Figure 1. Relatively similar results are obtained when estimating a second VAR using the bilateral exchange rate to the Euro (EURTND) instead of the US dollar and the money market rate (TMM) rather than the CBT's policy rate (Figure 16 and Appendix II. Figure 2). We find that a shock on the policy rate of one standard deviation ( +0.2 percentage points) leads to a decrease of inflation and real GDP growth of about 0.2 and 0.4 percentage points respectively after six quarters (Figure 15). A similar shock on the MMR (TMM) generates relatively similar results, with the 
impulse responses showing slightly more disturbance due the higher volatility of the MMR compared to the policy rate (Figure 8).

The empirical evidence also suggests strengthening interest rate transmission in the recent period. The coefficient associated with the policy rate lag in the equation where inflation is the dependent variable is statistically significant at a confidence level of 95 percent over the period 2010Q12019Q4. Interestingly, the statistical significance of the coefficient relating to the policy rate in the equation where inflation is the dependent variable has been increasing over time (Table 1). The other variables that drive inflation developments in Tunisia - the exchange rate and broad money_are also statistically significant at the 95 percent confidence level ( $p$-value $<0.05$ ).

The variance decomposition of inflation shows that about 13 percent of inflation variance is explained by the changes of the policy rate (after 9 quarters); a similar percentage of inflation variance (13 percent) is due to changes in broad money growth, while exchange rate fluctuations explain up to 40 percent of inflation variability over the long-run. The variance decomposition of inflation also reveals a decreasing persistence of inflation over time and increasing role of the exchange rate in explaining inflation fluctuations (Figure 17 and Appendix II. Figure 3). On the other hand, the variance decomposition of real GDP growth suggests a very limited role of broad money in explaining economic growth developments, consistent with the long run money neutrality (Figure 18).

\begin{tabular}{|lrrrr|}
\hline \multicolumn{5}{|l|}{ Table 1. Significance Level of the Policy Rate Coefficient } \\
\hline & \multicolumn{4}{l}{ Estimation period } \\
\cline { 2 - 5 } & 2010Q1-2019Q3 & 2010Q1-2018Q4 & 2010Q1-2017Q4 & 2010Q1-2016Q4 \\
\hline $\begin{array}{l}\text { Policy Rate } \\
\text { Coefficient }\end{array}$ & -0.35 & -0.39 & -0.33 & -0.18 \\
\hline P-value & 0.0180 & 0.0291 & 0.1091 & 0.4932 \\
\hline & & & & \\
\hline
\end{tabular}

Figure 15. VAR with the US Dollar Exchange Rate and the Policy Rate-Responses of Inflation and Output to a Policy Rate Shock

Response of PI to BCT_RATE

Response of GR to BCT_RATE

4

.2

.0

$-.2$

$-.4$

Sources: Tunisian authorities and authors' calculations.
1.2

0.8

0.4

0.0

$-0.4$

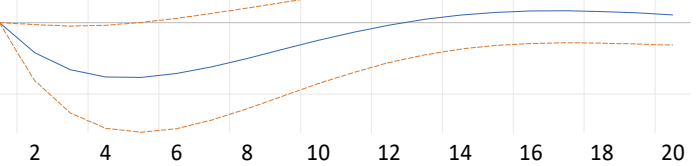



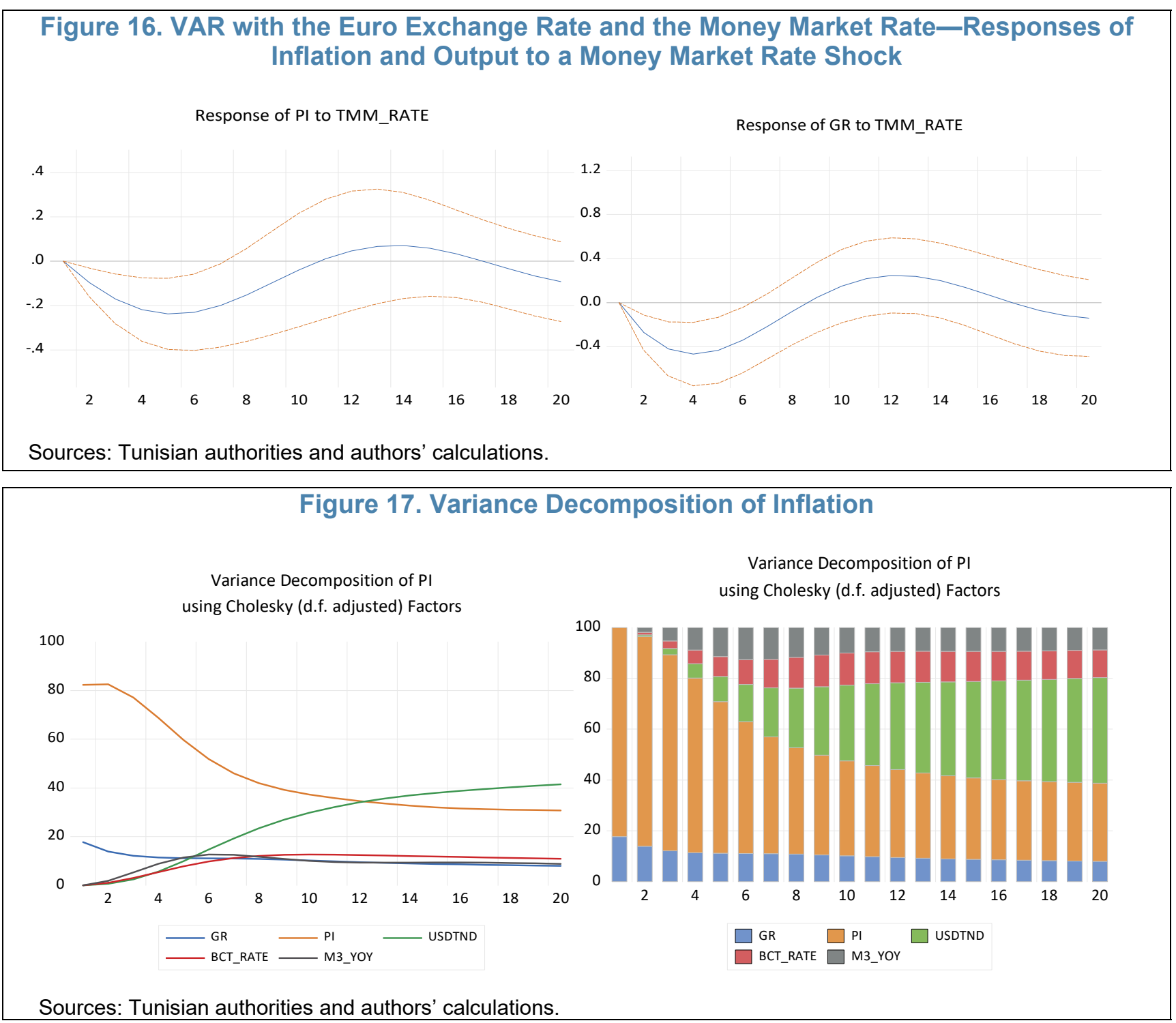

Sources: Tunisian authorities and authors' calculations.

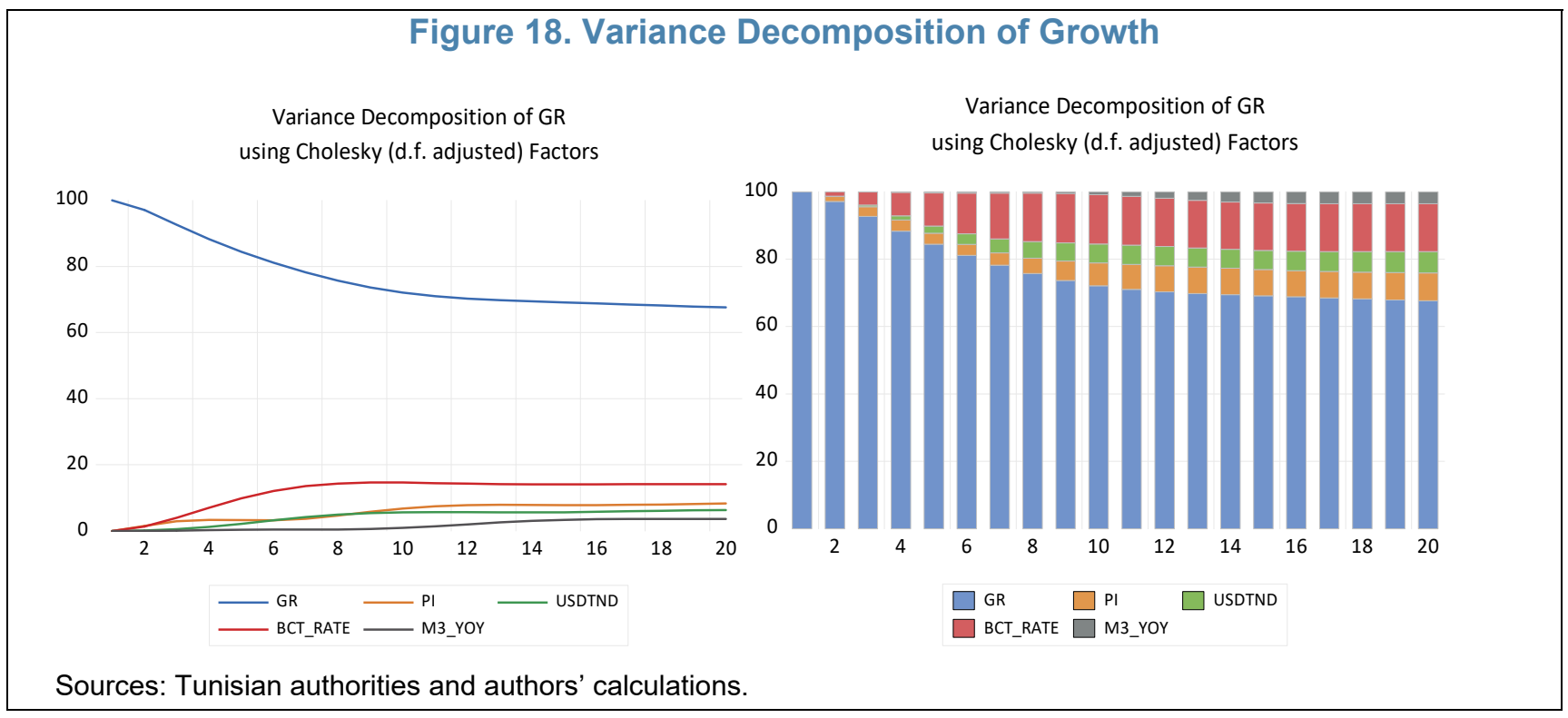

CInternational Monetary Fund. Not for Redistribution 


\section{B. Passthrough from the Policy Rate to the Money Market Rate}

Following Gigineishvili (2011), we estimate the following equation using daily data of the policy rate and the MMR:

$$
i_{t}^{M M R}=\theta+\sum_{k=0}^{n} \beta_{k} i_{t-k}^{\text {Poliy Rate }}+\sum_{k=1}^{n} \alpha_{k} i_{t-k}^{M M R}+\varepsilon_{t}
$$

where the $\beta_{k}{ }^{\prime}$ s are the short-run elasticities, while $\alpha_{k}{ }^{\prime} s$ reflect the persistence of the MMR. The long-run policy rate pass-through coefficient is then calculated as $\beta=\left(\sum_{k=0}^{n} \beta_{k}\right) /\left(1-\sum_{k=1}^{n} \alpha_{k}\right)$. We find that the long-run policy rate pass-through coefficient weakened from 1 over the period January 10, 2015-July 11, 2017, to 0.88 over the period July 12, 2017-April 30, 2019-the window after the cap on the outstanding volume of the 7-day MRO was introduced.

The transmission from the policy rate to bank retail rates is however effective: bank deposit and lending rates co-move with the CBT's policy rate (Figure 19).

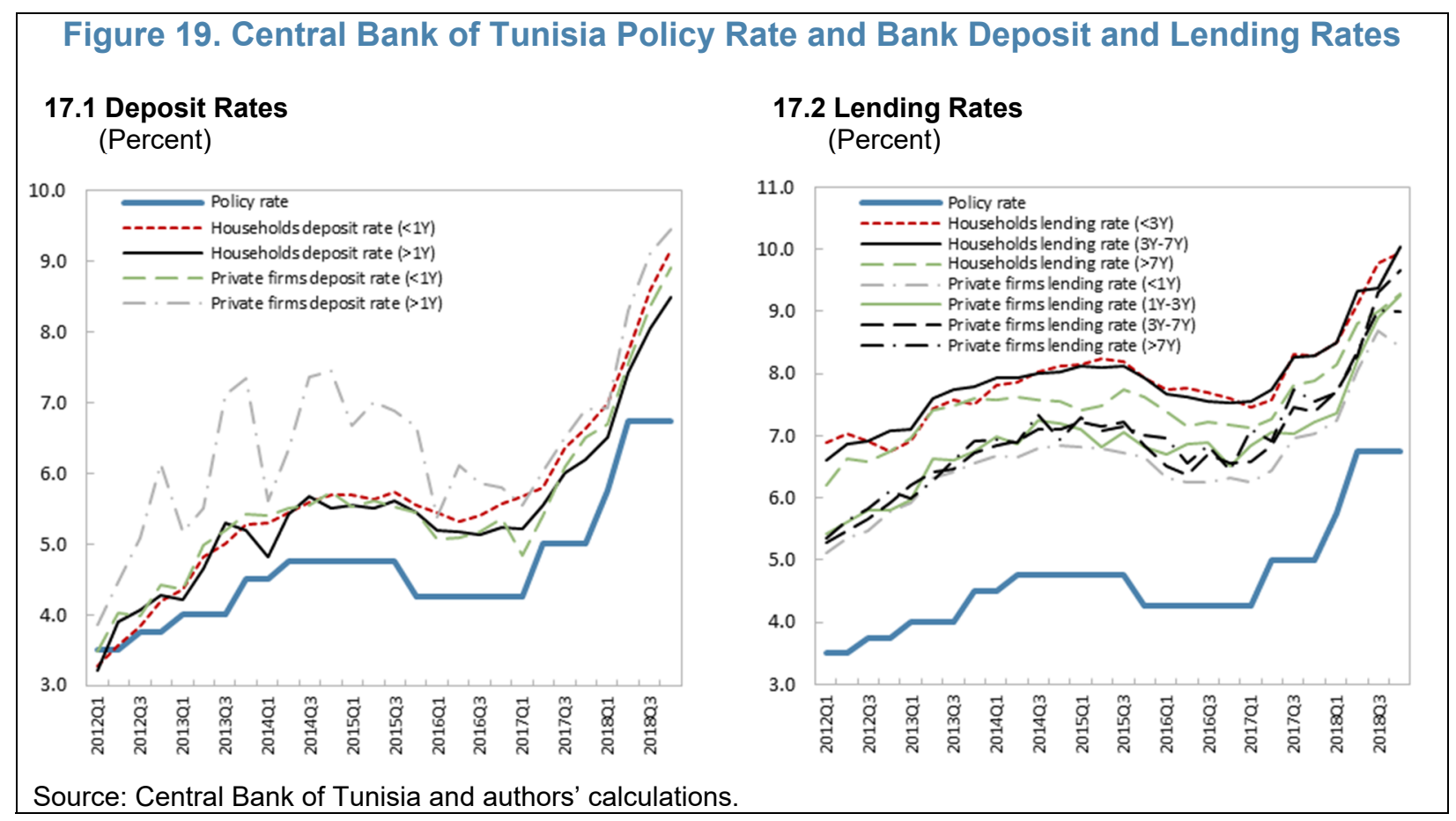

\section{Exchange Rate Passthrough to Inflation}

Changes in the exchange rate are expected to impact domestic prices - this is the exchange rate passthrough. In Tunisia, the consumption basket that composes the consumer price index (CPI) contains an important share of imported goods; therefore, a depreciation of the dinar should have an important impact on domestic prices (unless importers or retailers compress their margins). On the other hand, many prices are regulated, which may mitigate the impact of a depreciation on domestic prices.

To estimate the magnitude of the exchange rate passthrough in Tunisia, we follow Burstein and Gopinath (2014) and estimate the following dynamic lag regression: 


$$
\Delta p_{t}=\alpha+\sum_{k=0}^{K} \beta_{k} \Delta s_{t-k}+\Gamma . \boldsymbol{X}_{t}+\varepsilon_{t}
$$

where $p_{t}$ is the CPI, $s_{t}$ is the dinar per US\$ exchange rate, and $\boldsymbol{X}_{t}$ a vector of control variables. We consider three categories of such controls: monetary developments (the growth in broad money) and production costs (changes in oil prices in US\$). The coefficients of interest are mostly $\beta_{0}$, i.e. the instantaneous passthrough; and $\mathrm{B}=\sum_{k=0}^{K} \beta_{k}$, i.e. the long-term passthrough. ${ }^{7}$

Given that the Jasmine Revolution represents a structural break for the Tunisian economy, we want to be able to isolate the 2011-19 period. In order to cover each subperiods with enough observations, we estimate the regression on a monthly frequency. Our main findings are threefold. ${ }^{8}$ First, we look at how the passthrough has evolved since the Revolution. We find that both the short- and long-term passthroughs were stronger during the first years that followed the change in the exchange rate arrangement (2010-15): the exchange rate passthrough increased when the CBT abandoned the stabilized exchange rate arrangement. This is also confirmed by estimating the passthrough on a moving estimation period (Figure 20). Second, we analyze how controlling for money growth alters our results. We found that the passthrough is somewhat stronger, especially in the long run, when we add the growth of broad money as explanatory variable. This is particularly visible in the 2016-19 period that saw more pronounced monetary

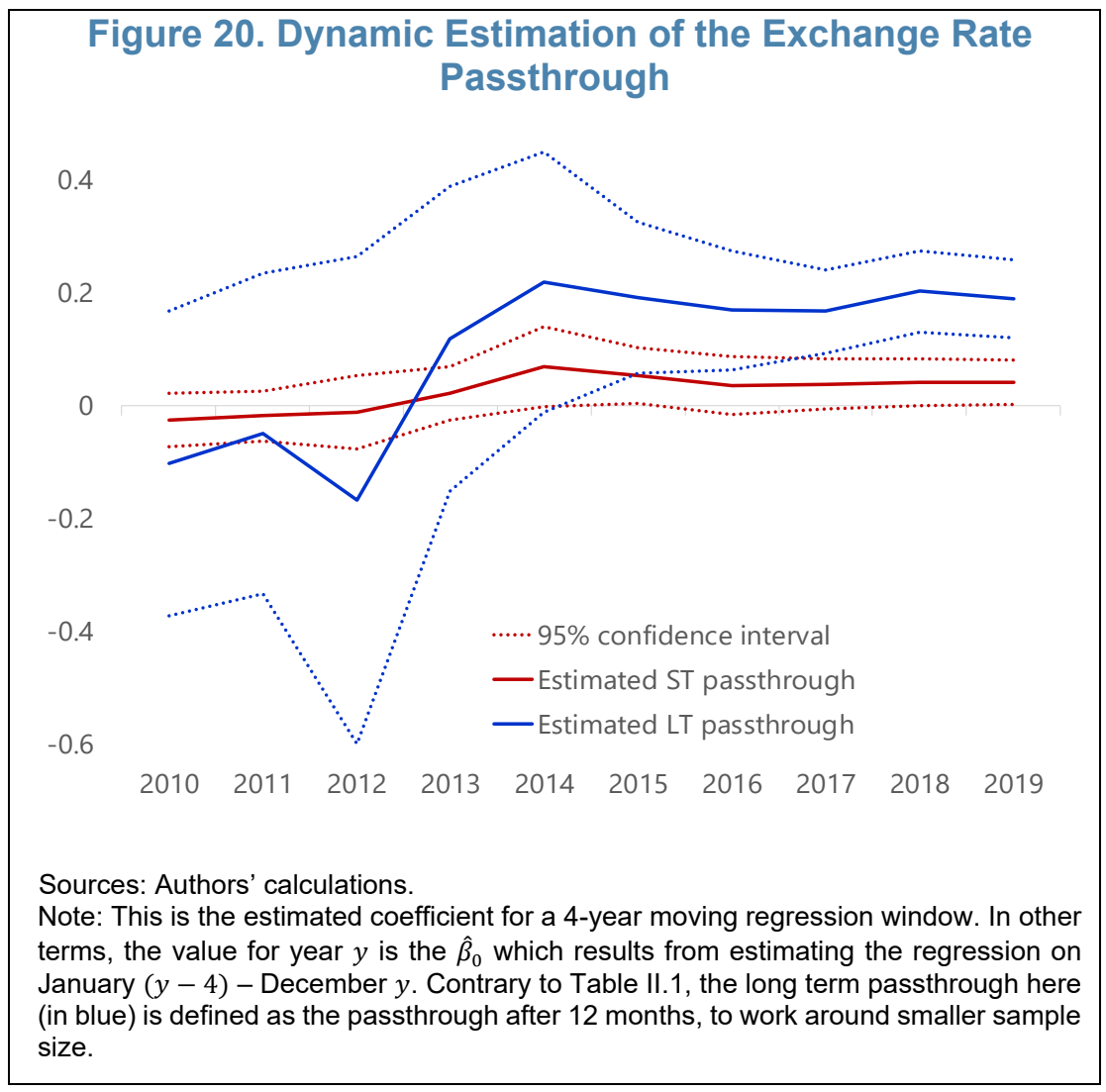

expansion, suggesting that the latter resulted in a stronger effect of the exchange rate depreciation on inflation. Third, we investigate whether prices respond asymmetrically to exchange rate shocks. ${ }^{9}$ We found that in the short run, appreciations tend to be reflected more in prices than depreciations. This is most likely the result of the large share of regulated prices in the economy,

\footnotetext{
${ }^{7}$ In order to get t-statistics and standard errors for the long-term passthrough, we actually estimate the following, arithmetically equivalent equation: $\Delta p_{t}=\alpha+\sum_{k=0}^{K-1} \beta_{k}\left(\Delta s_{t-k}-\Delta s_{t-K}\right)+\mathrm{B} \Delta s_{t-K}+\boldsymbol{\Gamma} . \boldsymbol{X}_{t}+\varepsilon_{t}$.

${ }^{8}$ Regression results are in Appendix II. As a robustness check, we also estimated the equation without the oil price variable to examine whether this might be driving our findings. Results remained similar.

${ }^{9}$ Specification with asymmetric effects: $\Delta p_{t}=\alpha+\sum_{k=0}^{K} \beta_{k}^{+} \Delta s_{t-k}^{+}+\beta_{k}^{-} \Delta s_{t-k}^{-}+\Gamma \cdot \boldsymbol{X}_{t}+\varepsilon_{t}$.
} 
that alters monetary transmission. However, this effect disappears in the longer run, when depreciations are marginally more impactful than appreciations.

\section{The WAY ForWARD: Moving TOWARD INFLATION TARgETING}

\section{A. The Case for Inflation Targeting}

The CBT is not a traditional monetary targeter. Under a monetary targeting framework, monetary policy implementation relies on the central bank's control over reserve money, with its evolution signaling when and why to intervene to attain reserve and broad money targets (Laurens and others 2015). This was not the way monetary policy operated in Tunisia over the 2010s. Indeed, before August 2018, the CBT's liquidity injections targeted credit growth, among other objectives, rather than reserve and broad money objectives consistent with low and stable inflation. The liquidity injections were, until very recently, collateralized at 60 percent with credits against 40 percent with

Figure 21. Domestic Credit to the Private Sector (Percent of GDP, 2017)

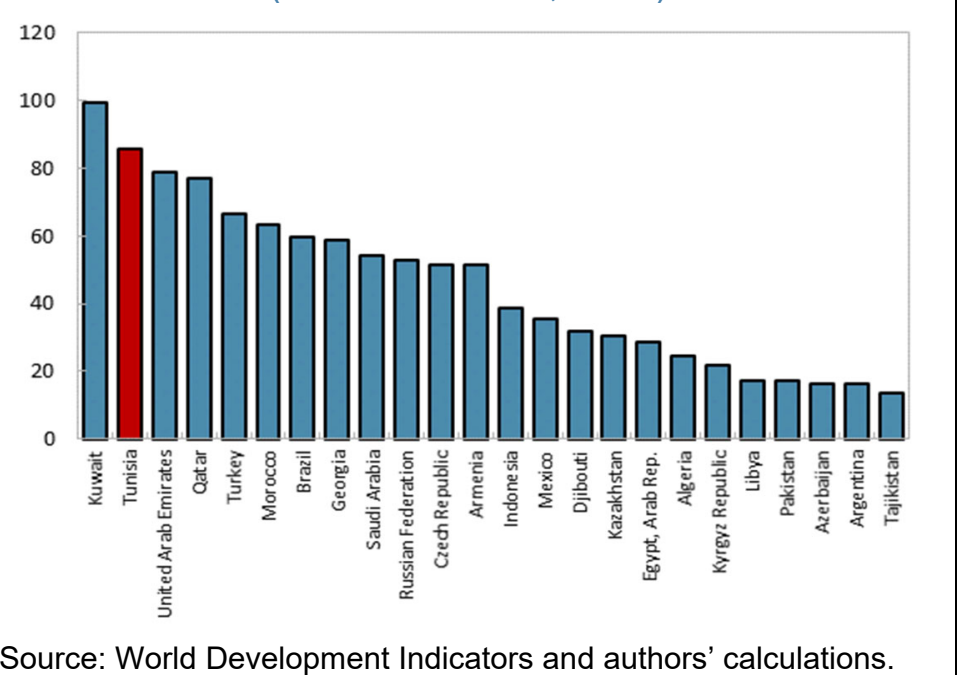
government securities. ${ }^{10}$ Since April 2020, the CBT's liquidity injections are collateralized at 50 percent with credits against 50 percent with government securities. Tunisia's credit-to-GDP ratio is among the highest in the region and compared to other emerging market economies (Figure 21).

Recent success with an interest rate-based monetary policy suggests that such a framework is more appropriate. Tunisia has been successful since 2018 in reverting a dangerous accelerating inflation trend through a series of hikes in the policy rate that brought key interest rates firmly into positive territory. In addition to the CBT's active use of its policy rate, several other prerequisites for a successful transition to IT are in place:

- Components of the CBT's monetary policy framework are already consistent with IT. The CBT cannot directly lend to the government, ${ }^{11}$ the central bank legal mandate is to ensure price stability, its implicit inflation target is four percent, and the $\mathrm{O} / \mathrm{N}$ interbank rate (i.e., MMR) is its operational target as stipulated in its regulation. ${ }^{12}$ The CBT operates a 200 basis points interest rate mid-corridor system and has already developed short-term forecasting models as

\footnotetext{
${ }^{10}$ The collateral policy was introduced in 2017 (CBT circular 2017-02). Previously, banks were able to present any collateral (public securities or credit claims) and no minimum threshold was required.

${ }^{11}$ Article 25 of Law No. 2016-35 of April 25, 2016 fixing the Statute of the Central Bank of Tunisia.

${ }^{12}$ Circular No. 2017-02 on the Implementation of Monetary Policy by the Central Bank of Tunisia.
} 
well as a medium-term Quarterly Projection Model (QPM) used to forecast inflation and support its monetary policy decisions. The monetary policy rule takes the form of a Taylor rule augmented with the exchange rate and the CBT signals its monetary policy stance through its policy rate.

- Monetary policy communication has been strengthened. The CBT is in a good position to publish a monetary policy report. The report "Evolutions Economiques et Monétaires et Perspectives à Moyen Terme" has already many features of an effective monetary policy report (Appendix VI). Since October 2018, the report has been published on a more regular basis and includes the CBT's inflation projections (Figure 22). The central bank also upgraded the report published in May 2019 by including a new section on international developments ("Conjoncture Internationale"). The CBT's monetary policy implementation regulation, forecasting models, and research papers are published on its website.

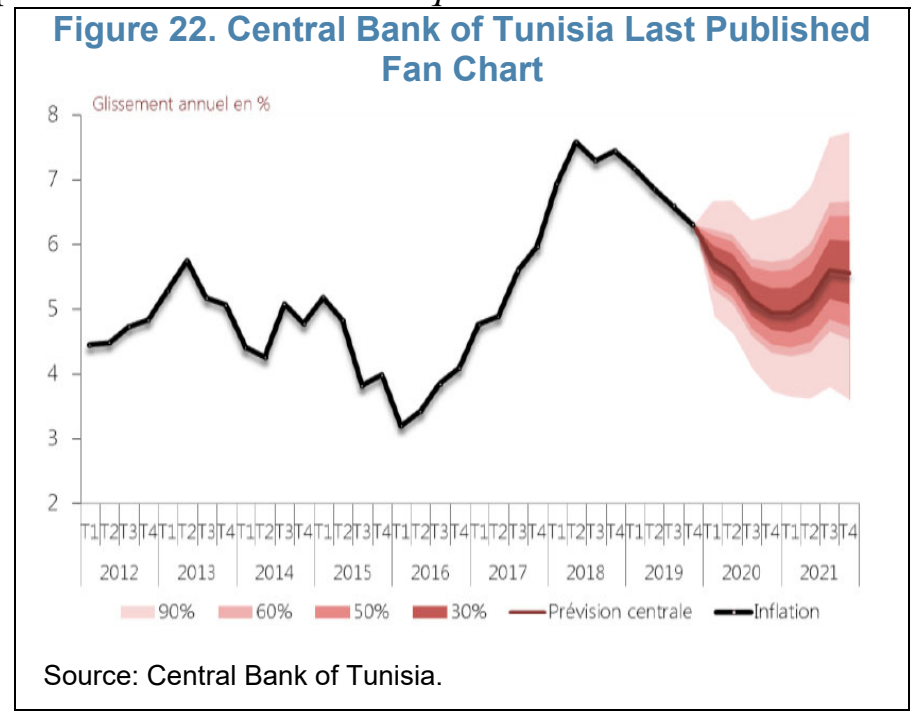

- The CBT's FX auctions have become more competitive, regular, and two-sided. The CBT introduced more competitive FX auctions in August 2018. Since December 2018, the auctions have become more frequent with smaller volumes to support price discovery. The CBT has also respected its monthly net intervention limits established under the Extended Fund Facility (EFF) arrangement since then and started to buy FX in March 2019. Competitive auctions and lower intervention volumes contributed to accelerated depreciation in the fourth quarter of 2018. The depreciation trend reverted in March 2019, mostly under the effect of tighter monetary policy as well as stronger tourism receipts and other FX flows related to privatizations, which together shifted expectations from depreciation to appreciation until February 2020.

\section{B. Next Steps to Support the Transition to Inflation Targeting}

Efforts should focus on further strengthening the monetary policy framework. Cross-country experience suggests that a full transition to IT may take time (Laurens and others, 2015); the time needed depends on countries' initial macro-financial conditions and the authority's willingness to move to IT. Based on the international experience and CBT's experience, the transition could include:

- Committing to a forward-looking rule-based monetary policy. The CBT has exerted some discretion in its monetary policy decisions that accounted for the economic slowdown and persistent negative output gap, as well as household vulnerabilities and financial developments in a difficult political context. However, discretionary monetary policy gives rise to timeinconsistency problem and comes at a high cost as workers and firms adjust wages and prices based on observed policy actions and expectations about inflation. Compared to a rule-based 
monetary policy, the result of discretionary monetary policy is often an equilibrium with higher inflation and lower growth. Establishing a clear nominal anchor helps prevent the timeinconsistency problem by providing an expected constraint on discretionary monetary policy decisions. ${ }^{13}$

- Announcing a medium-term inflation objective. An explicit numerical inflation target could be announced as an effective way to operationalize the CBT's price stability mandate. A transparent and credible inflation objective in turn helps anchor inflation expectations and provides a simple and transparent benchmark against which to measure performance. The inflation objective needs to be both achievable and, over time, achieved to be credible (IMF, 2015).

- Strengthening interest rate transmission. The distortions that continue to alter the monetary transmission mechanism should be addressed. The CBT operates an interest rate mid-corridor system with its MRO allocated through variable rate auctions; consequently, the volume of the MRO should be calibrated with reference to autonomous factors' forecasts, but also to prevent the pressure from a full-allotment on the exchange rate. The collateral policy already became more balanced (50 percent of government securities as collateral), with the main objective of protecting the central bank balance sheet against risks.

- Upgrading the CBT's analytical capacity and macro-forecasting models. The CBT is already well advanced in the development of a suite of forecasting models. Under its partnership with the Banque de France, the CBT developed a QPM and short-term forecasting models (ARIMA) currently used to project inflation. In addition, in the context of its 2019-21 strategic plan, the CBT currently works on developing a Dynamic Stochastic General Equilibrium (DSGE) model and can benefit from the development of an inflation expectations survey.

- Strengthening communications, transparency, and accountability. The CBT could continue its efforts to strengthen policy communications to focus the latter more on inflation projections and outcomes. It can also provide insight into how the monetary policy framework operates in an integrated manner. Effective communications help reduce uncertainty, improve monetary policy transmission, and facilitate accountability. All this will help to reinforce credibility and anchor expectations.

\footnotetext{
${ }^{13}$ Optimal monetary policy should not try to exploit the short-run tradeoff between unemployment and inflation by pursuing overly expansionary policy because decisions about wages and prices reflect expectations about policy made by workers and firms; when they see a central bank pursuing expansionary policy, workers and firms will raise their expectations about inflation, and push wages and prices up. The rise in wages and prices will lead to higher inflation but will not result in higher output on average. A strong nominal anchor can help ensure that the central bank will focus on the long run and resist the temptation or the political pressures to pursue short-run expansionary policies that are inconsistent with the long-run price stability goal (Mishkin, 2006). Policymakers should follow rules rather than have discretion (Kydland and Prescott, 1977).
} 
Figure 23. Monetary Conditionality and the Evolving Monetary Policy Framework in Tunisia

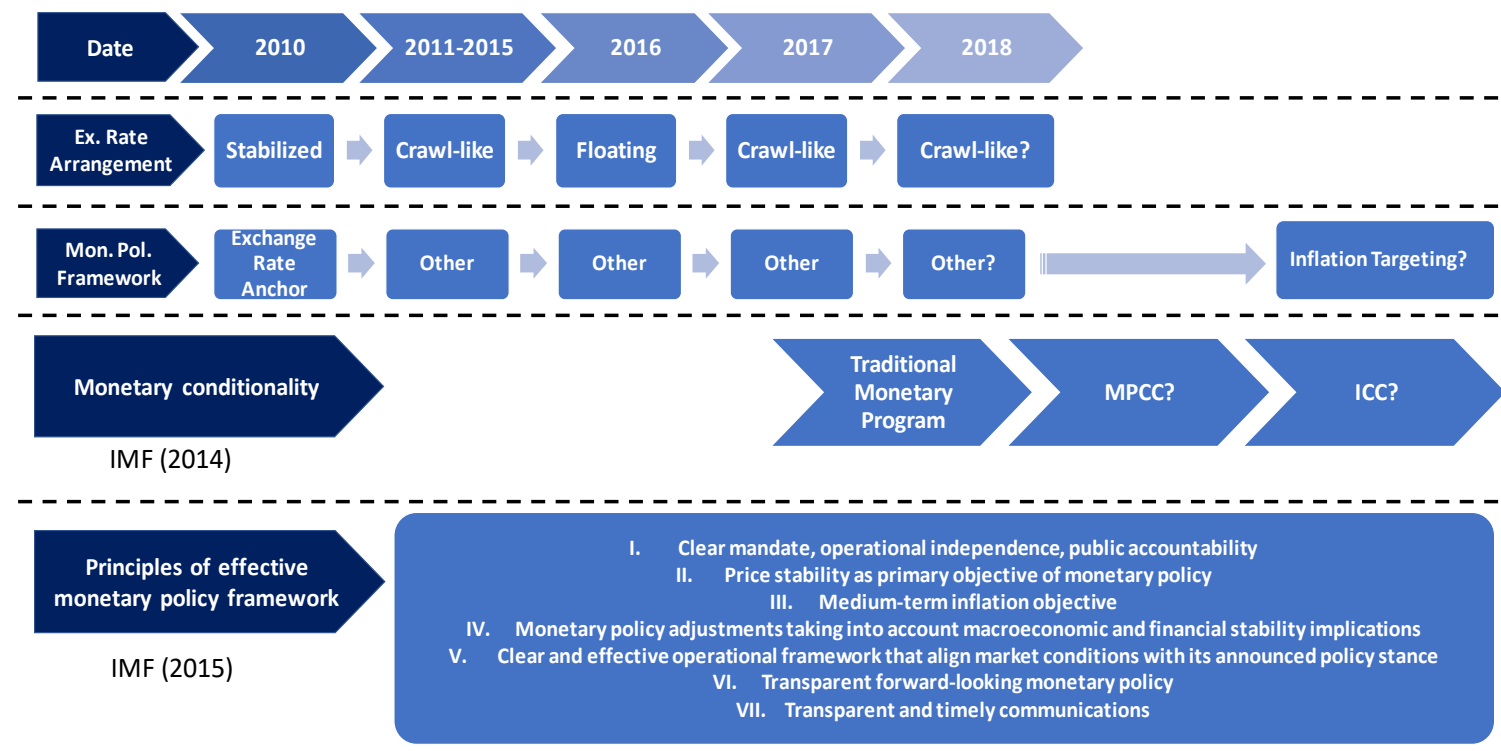

Sources: IMF AREAERs and IMF (2014 and 2015).

\section{Conclusion}

The key findings of this paper are consistent with the long run money neutrality and time inconsistency problem that a discretionary monetary policy, without a clear nominal anchor, can face. The 2016-18 central bank's balance sheet expansion - and simultaneous increase in broad money and credit growth - haven't generated any additional economic growth that averaged 1.8 percent during 2016-19, a level similar to the precedent period (2011-15). Interestingly, real GDP growth averaged 4.4 percent over 2007-10, a period during which the CBT was not conducting liquidity injection operations at its initiative as the banking system was in structural liquidity surplus. CBT's intention to move further with the modernization of its monetary policy framework while maintaining exchange rate flexibility is expected to reduce the real costs of the current disinflation process through an effective anchoring of expectations of economic agents.

We argue for clarifying the monetary policy framework and conducting a more rule-based monetary policy to avoid the time inconsistency problem and better anchor inflation expectations. In our view, the move to IT is also justified by an already functioning interest rate transmission that should be strengthened over time with supportive communication and a clear nominal anchor. Sound communication and monetary policy design and implementation are expected, on their turn, to contribute to increasing central bank credibility. At the same time, the level of financial development does not appear to be a constraint to the implementation of IT, as monetary transmission works through the banking sector though financial markets are still shallow. The Tunisian financial sector is already more developed than some countries that are already inflation targeters.

Finally, the CBT has been established as an independent central bank that cannot directly lend to the government according to article 25 of its Law. Remaining independent and free from fiscal dominance is critical as the literature and international experience have revealed this as a prerequisite for the successful transition to IT. 
Appendix I. Central Bank of Tunisia Simplified Balance Sheet and the Structural Liquidity Position of the Banking Sector

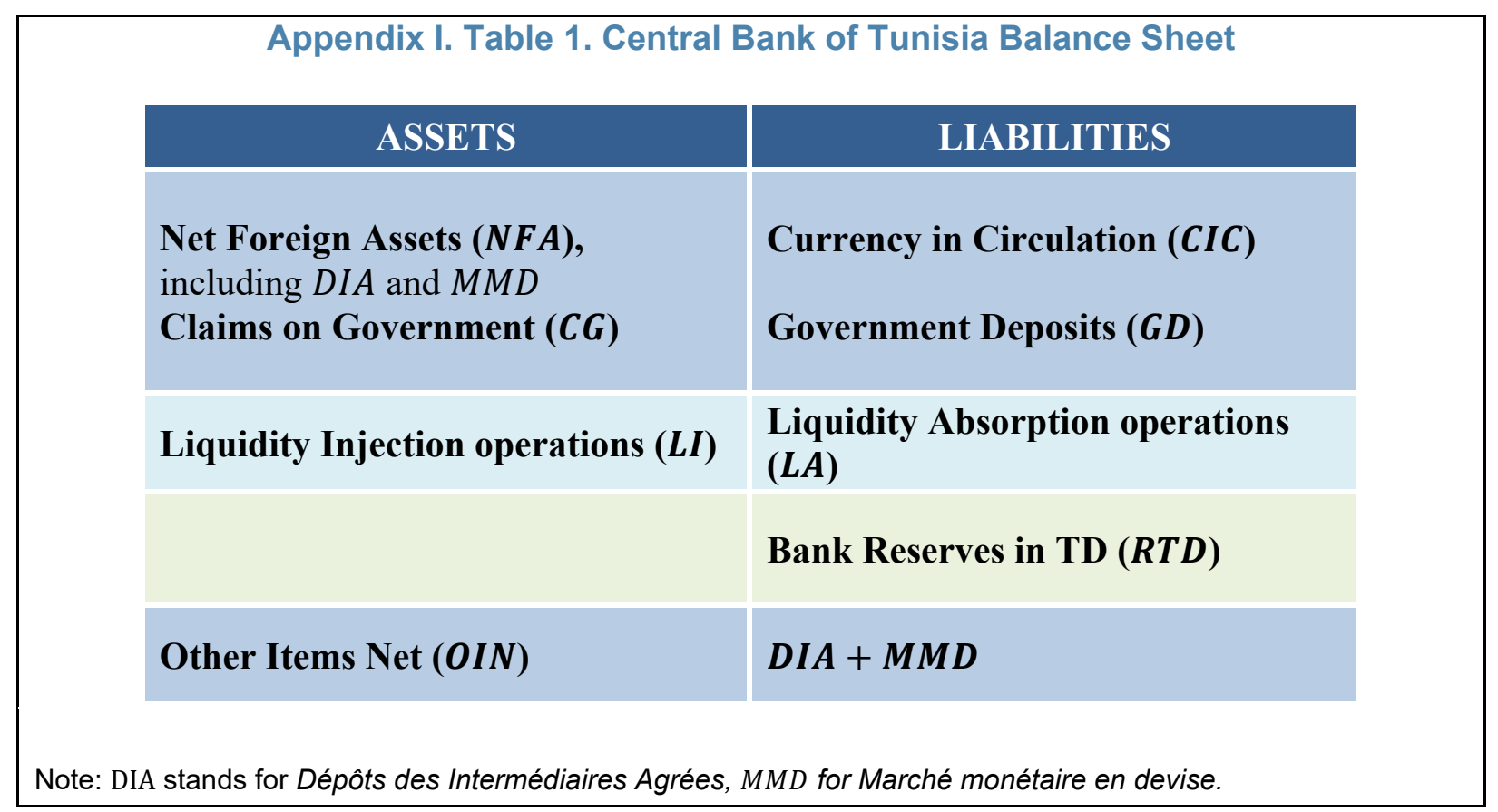

From the accounting ASSETS = LIABILITIES identity, one can decompose bank reserves in dinar as:

$$
R T D=(N F A+C G+O I N-C I C-G D-D I A-M M D)+(L I-L A)
$$

The first term comprises autonomous liquidity factors $(A L F)$, the second is the result of CBT monetary operations (CBTMO):

$$
R T D=A L F+C B T M O
$$

Hence:

Structural Liquidity Position $=R T D-C B T M O=A L F$ 


\section{Appendix II. VAR Impulse Responses, Variance Decomposition, and Exchange Rate Passthrough Estimation Results}

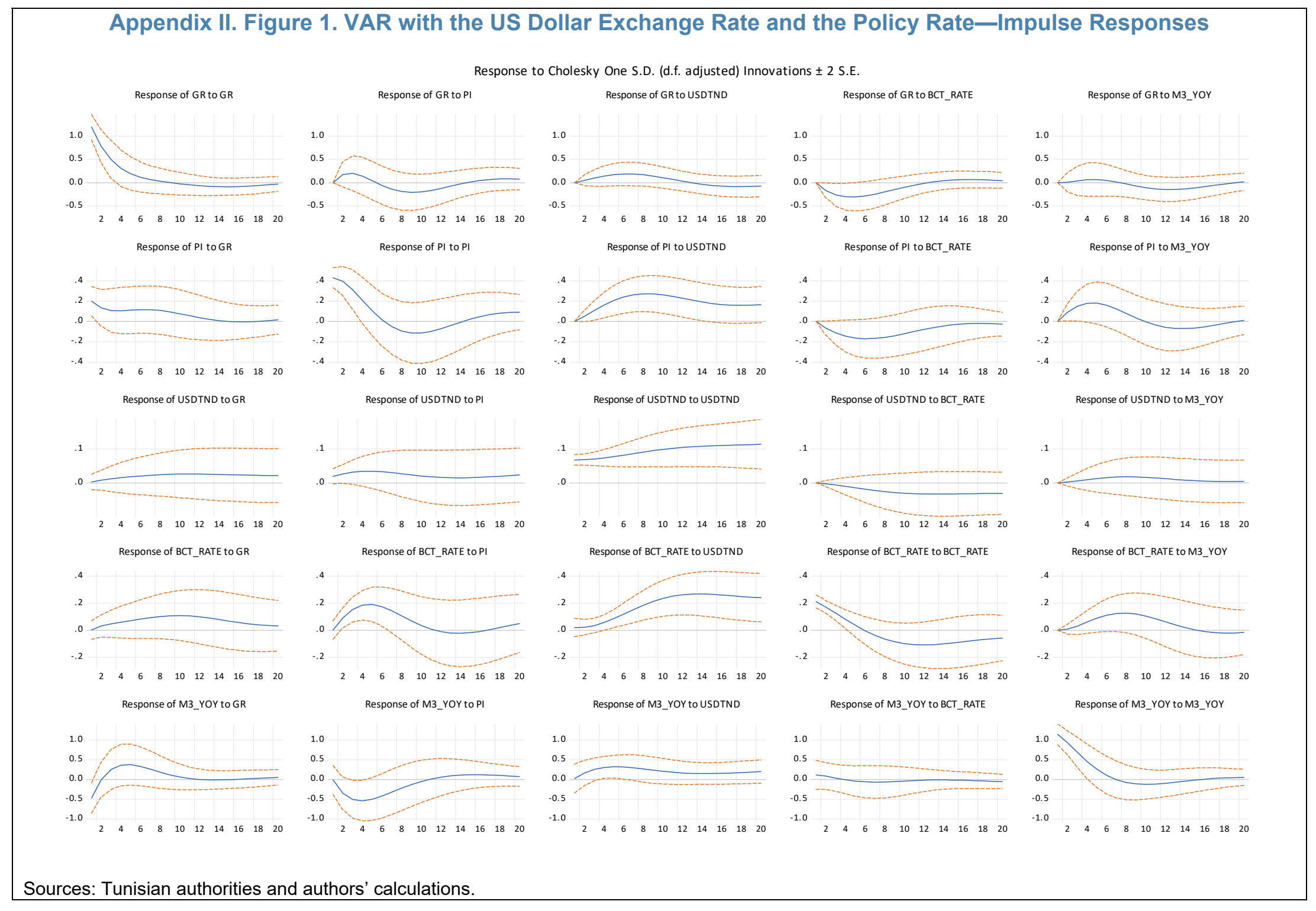




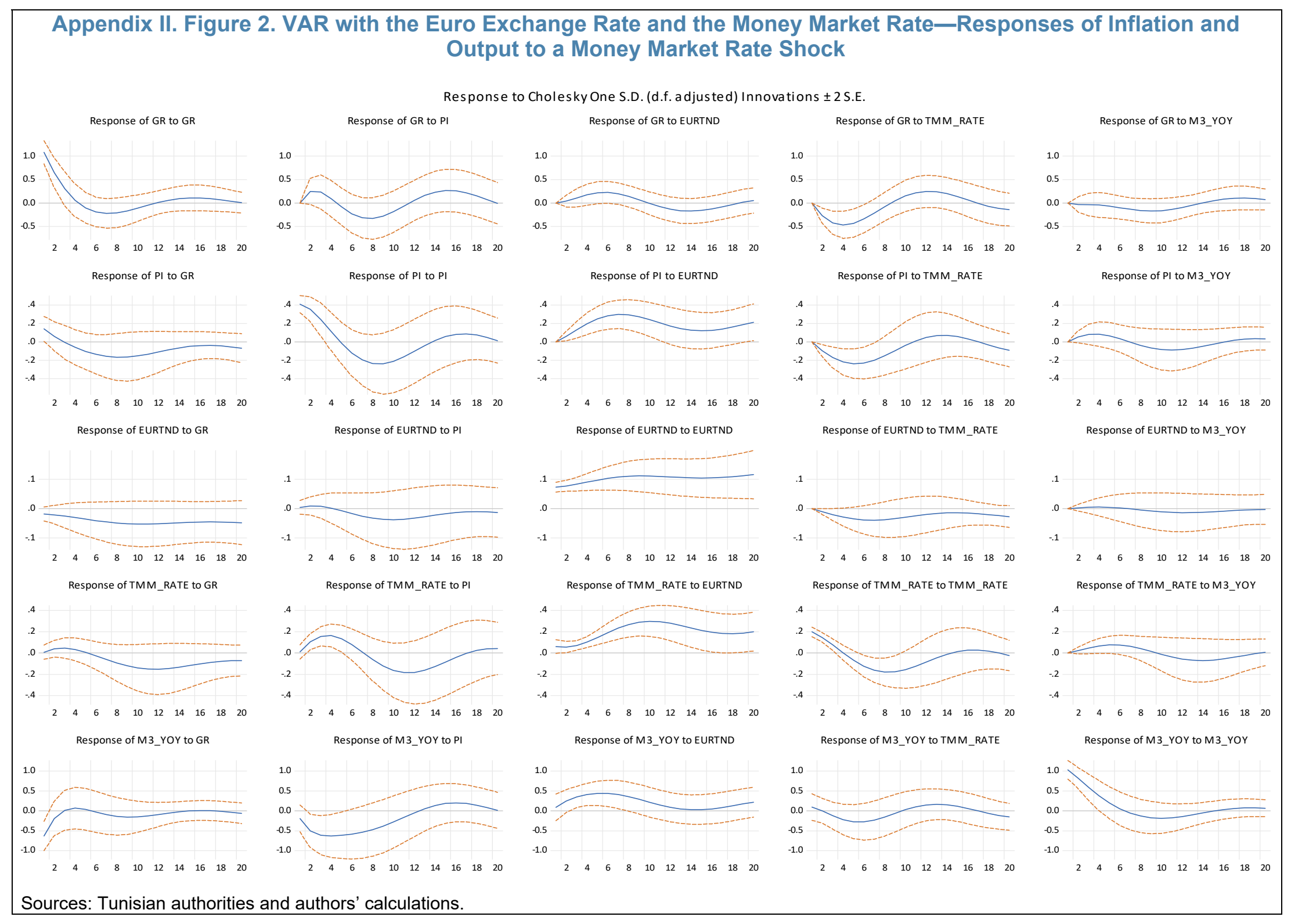




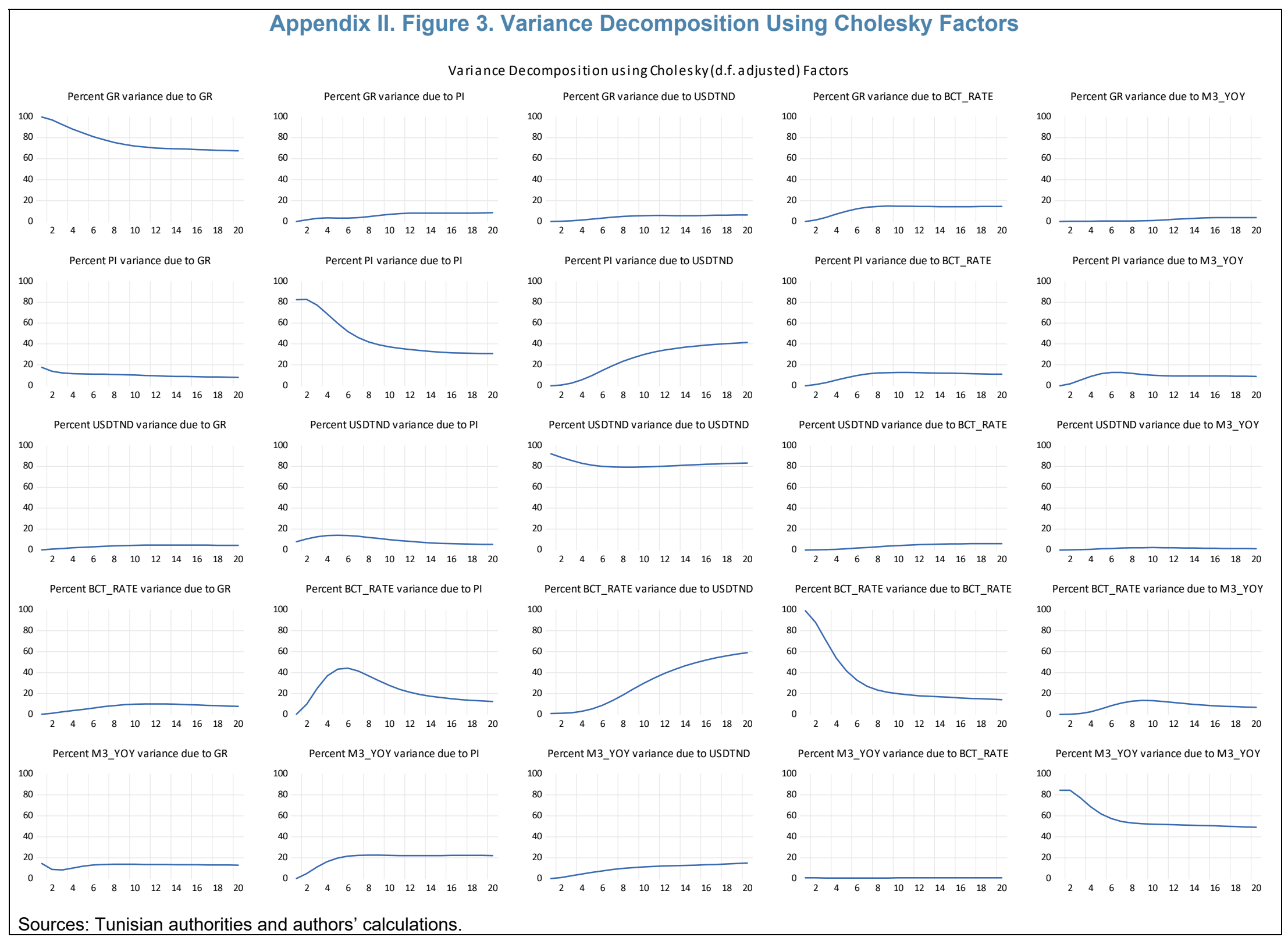




\begin{tabular}{|c|c|c|c|c|c|c|c|c|c|c|c|}
\hline \multicolumn{12}{|c|}{ Appendix II. Table1. Regression Results } \\
\hline & \multicolumn{4}{|c|}{ Baseline } & \multicolumn{3}{|c|}{ With money variable } & \multirow[b]{2}{*}{ 2016-2019 } & \multicolumn{3}{|c|}{ With asymmetric effects } \\
\hline & 2003-2019 & 2010-2019 & 2010-2015 & 2016-2019 & 2003-2019 & $2010-2019$ & $2010-2015$ & & 2003-2019 & $2010-2019$ & 2010-2015 \\
\hline & (1) & (2) & (3) & (3) & (4) & (5) & (6) & (7) & (8) & (9) & (10) \\
\hline$\Delta$ Oil & $\begin{array}{r}0.0007 \\
(0.0022)\end{array}$ & $\begin{array}{r}-0.0008 \\
(0.0032)\end{array}$ & $\begin{array}{l}-0.0065 * \\
(0.0033)\end{array}$ & $\begin{array}{r}0.0030 \\
(0.0078)\end{array}$ & $\begin{array}{r}0.0006 \\
(0.0023)\end{array}$ & $\begin{array}{r}-0.0012 \\
(0.0030)\end{array}$ & $\begin{array}{l}-0.0071^{* *} \\
(0.0031)\end{array}$ & $\begin{array}{r}0.0031 \\
(0.0071)\end{array}$ & 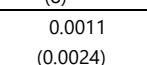 & $\begin{array}{l}-0.0065 * * \\
(0.0030)\end{array}$ & $\begin{array}{l}-0.0159 * \\
(0.0077)\end{array}$ \\
\hline beta0 & 0.0197 & 0.0380 * & 0.0792 ** & 0.0108 & 0.0213 & 0.0426 ** & 0.0802 ** & 0.0179 & 0.0495 & 0.1334 *** & $0.3199^{* * *}$ \\
\hline betaDepro & & & & & & & & & $\begin{array}{l}(0.0339) \\
-0.0409 \\
(0.0446)\end{array}$ & $\begin{array}{l}(0.0369) \\
-0.1219 * * \\
(0.0566)\end{array}$ & $\begin{array}{l}(0.0426) \\
-0.2783 * * \star \\
(0.0743)\end{array}$ \\
\hline B & $0.2357^{* * *}$ & $0.2628 * * \star$ & $0.3590^{* * *}$ & $0.2652 * * *$ & $0.2392 * * *$ & $0.2684 * * *$ & $0.3534 * * *$ & $0.2721 * * *$ & 0.1751 & $0.4175 * * *$ & $1.0591 * * \star 1$ \\
\hline Bdepr & & & & & & & & & $\begin{array}{r}0.0720 \\
(0.1863)\end{array}$ & $\begin{array}{l}-0.1919 \\
(0.2066)\end{array}$ & $\begin{array}{r}0.0166 \\
(0.8162)\end{array}$ \\
\hline$\Delta \mathrm{M} 3$ & & & & & $\begin{array}{l}-0.0032 \text { * } \\
(0.0017)\end{array}$ & $\begin{array}{l}-0.0030 \text { ** } \\
(0.0014)\end{array}$ & $\begin{array}{l}-0.0031 * \\
(0.0017)\end{array}$ & $\begin{array}{r}-0.0029 \\
(0.0046)\end{array}$ & & & \\
\hline Constant & $\begin{array}{l}0.0024 \text { *** } \\
(0.0003)\end{array}$ & $\begin{array}{l}0.0028 \text { *** } \\
(0.0002)\end{array}$ & $\begin{array}{l}0.0026 \text { *** } \\
(0.0005)\end{array}$ & $\begin{array}{l}0.0024 \text { *** } \\
(0.0007)\end{array}$ & $\begin{array}{l}0.0024 \text { *** } \\
(0.0003)\end{array}$ & $\begin{array}{l}0.0027 \text { *** } \\
(0.0002)\end{array}$ & $\begin{array}{l}0.0025 \text { *** } \\
(0.0005)\end{array}$ & $\begin{array}{l}0.0024 \text { *** } \\
(0.0008)\end{array}$ & $\begin{array}{l}0.0022 \text { *** } \\
(0.0008)\end{array}$ & $\begin{array}{l}0.0035 \text { *** } \\
(0.0010)\end{array}$ & $\begin{array}{r}0.0010 \\
(0.0038)\end{array}$ \\
\hline Observations & 211 & 116 & 72 & 44 & 211 & 116 & 72 & 44 & 211 & 116 & 72 \\
\hline
\end{tabular}




\section{Appendix III. Definition of Monetary Policy Frameworks and Anchors}

The IMF AREAER defines three monetary policy frameworks with a clearly identified nominal anchor: (1) Exchange Rate Anchor; (2) Monetary Aggregate Target; and (3) IT Framework (IMF, 2018a). Countries such as Tunisia that have no explicitly stated nominal anchor but rather monitor various indicators in conducting monetary policy are classified under "other" by the AREAER. Under an Exchange Rate Anchor, the monetary authority buys or sells FX to maintain the exchange rate at its predetermined level or within a range. The exchange rate thus serves as the nominal anchor or intermediate target of monetary policy. These frameworks are associated with exchange rate arrangements with no separate legal tender, currency board arrangements, pegs (or stabilized arrangements) with or without bands, crawling pegs (or crawl-like arrangements), and other managed arrangements.

Under a Monetary Aggregate Targeting regime, the monetary authority uses its instruments to achieve a target growth rate for a monetary aggregate, such as reserve money, M1, or M2; the targeted aggregate becomes the nominal anchor or intermediate target of monetary policy. IT involves the public announcement of numerical targets for inflation, with an institutional commitment by the monetary authority to achieve these targets, typically over a medium-term horizon. Additional key features normally include increased communication with the public and the markets about the plans and objectives of monetary policymakers and increased accountability of the central bank for achieving its inflation objectives. Monetary policy decisions are often guided by the deviation of forecasts of future inflation from the announced inflation target, with the inflation forecast acting (implicitly or explicitly) as the intermediate target of monetary policy (Table 1 and figure 2).

\begin{tabular}{|c|c|c|c|}
\hline \multicolumn{4}{|c|}{ Appendix III. Figure 1. Monetary Policy Frameworks-The Building Blocks } \\
\hline & & \multicolumn{2}{|c|}{ The Operational Framework } \\
\hline $\begin{array}{c}\text { Policy } \\
\text { objective }\end{array}$ & $\begin{array}{l}\text { Intermediate } \\
\text { target }\end{array}$ & $\begin{array}{l}\text { Operating } \\
\text { target }\end{array}$ & $\begin{array}{l}\text { Monetary } \\
\text { instruments }\end{array}$ \\
\hline $\begin{array}{l}\text { - Final goal of } \\
\text { monetary policy } \\
\text { - Achievement is } \\
\text { the sole } \\
\text { responsibility of } \\
\text { the central bank }\end{array}$ & $\begin{array}{l}\text { - Guide to policy } \\
\text { decisions } \\
\text { - Allows policy to } \\
\text { satisfy its } \\
\text { objective with } \\
\text { greater precision }\end{array}$ & $\begin{array}{l}\text { - Guide to } \\
\text { ongoing central } \\
\text { bank operations } \\
\text { - Set to satisfy } \\
\text { intermediate } \\
\text { target over time } \\
\text { - Signals stance } \\
\text { of policy }\end{array}$ & $\begin{array}{l}\text { - Tools used to } \\
\text { achieve the } \\
\text { operational } \\
\text { target } \\
\text { - List of } \\
\text { counterparties } \\
\text { and accepted } \\
\text { collateral }\end{array}$ \\
\hline
\end{tabular}




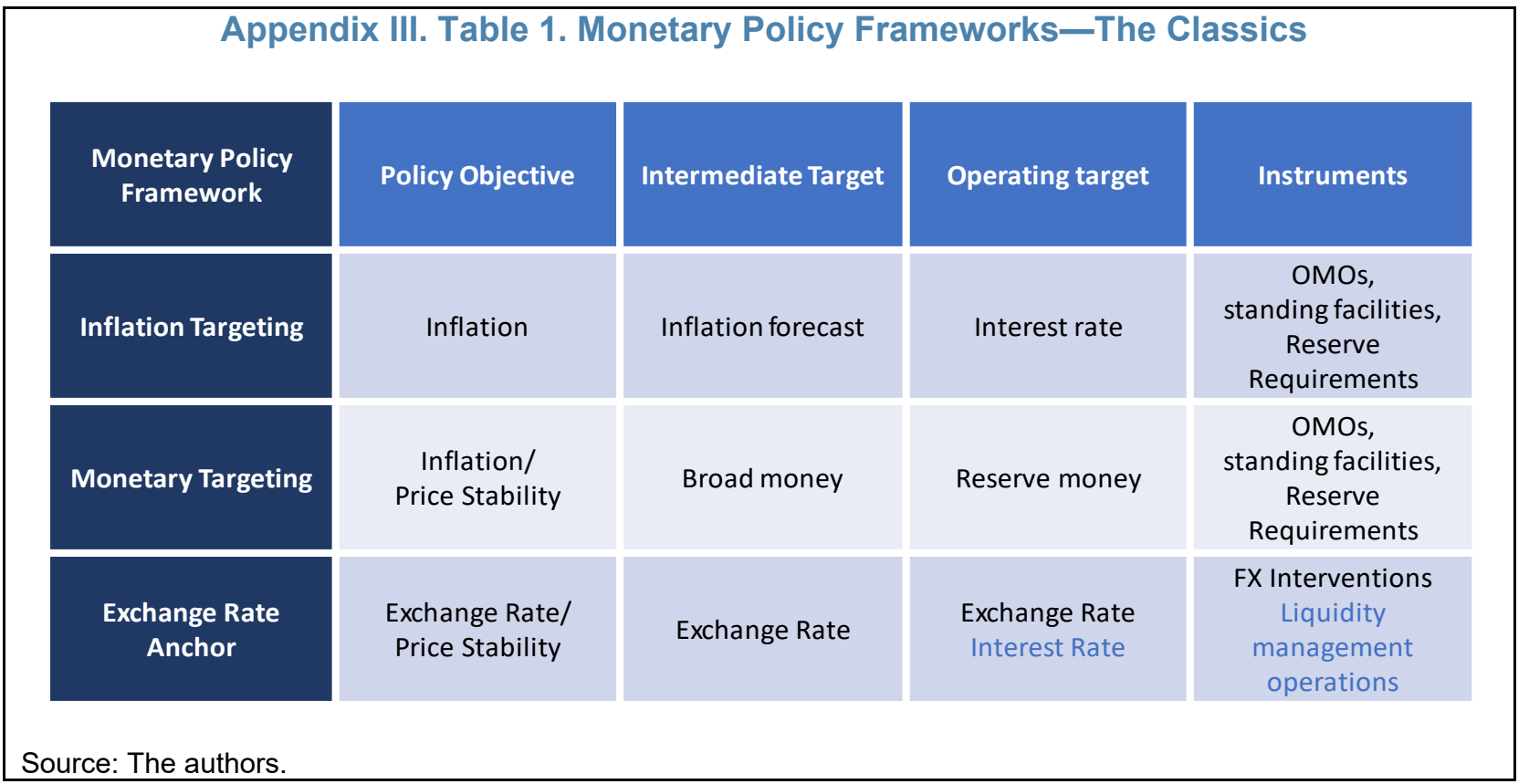




\section{Appendix IV. Primacy of Price Stability Versus Multiple Monetary Objectives ${ }^{1}$}

\section{Targeting multiple monetary policy objectives can result in a loss of monetary policy} effectiveness and credibility. In 1998, India adopted a "multiple indicator approach" where a number of quantity and rate variables were targeted but there was no explicit nominal anchor or clear primacy of price stability over other objectives. While initially successful, persistently high inflation led to increased dissatisfaction with the approach. Flexible IT was put forward in early 2014 and was officially adopted by the Reserve Bank of India in February 2015, with CPI inflation as targeted measure and a medium-term inflation objective of 4 percent with a band of $+/-$ 2 percent. A two-year "glide path" for reducing inflation toward this target was also laid out. India's experience thus far suggests that a clear inflation objective can strengthen policy communication and help anchor expectations.

Sustained deviations from the inflation objective can lead to a loss of credibility and with it the ability of the central bank to fulfill its price stability mandate. Once the public and financial markets lose trust in the central bank to deliver stable inflation, achieving this objective becomes near-impossible. Experience shows that prioritizing the price stability objective is a necessity, especially when the credibility of the central bank to deliver price stability is low. Allowing inflation expectations to become unanchored in such cases can pose severe risks to the stability of the real economy and the financial system, thus impairing the capacity of the central bank to fulfill any of these objectives and undermining the economy's long-run growth and the welfare of its population.

Central banks with sufficient credibility have more room to manage the policy trade-offs arising from conflicting objectives. When inflation expectations remain firmly anchored, the central bank has enhanced flexibility to take actions to promote macroeconomic and financial stability. Such central banks may more easily afford to ignore sharp increases in inflation, which they consider temporary. For example, in mid-2008, the Czech National Bank cut interest rates despite the fact that inflation was almost twice as high as the inflation target. The oil price shocks of the 1970's caused a large spike in inflation, but similar shocks since the late 1990's have had much smaller effects in developed countries. Blanchard and Gali (2007) find that the proven commitment to maintaining low inflation and enhanced credibility of central banks was an important factor in improving the trade-offs associated with oil shocks. For less credible regimes, prioritizing price stability may mean responding more aggressively to inflation shocks than would have seemed appropriate from the perspective of other objectives.

Most central banks have multiple high-level objectives, but there are very strong reasons to keep price stability as the focal point of monetary policy. In addition to price stability, central banks may care about growth, financial stability, the exchange rate, and/or financial sector development. These objectives can come into conflict. A key lesson from the international experience is that keeping the price stability objective as the focal point of monetary policy, and the resulting anchoring of inflation expectations, can provide the central bank with more room to manage the difficult trade-offs involved and to decide on the preferred magnitude and pace of policy adjustment and horizon for bringing inflation back to target. Prudential policies should continue being used as the first line of defense against financial risks.

\footnotetext{
${ }^{1}$ Source: IMF (2015).
} 


\section{Appendix V. Tunisia Financial Development-Comparison to Peers}

\section{Appendix V. Figure 1. Financial Development Index of MCD Countries (2017)}

MCD: FD

$\equiv$

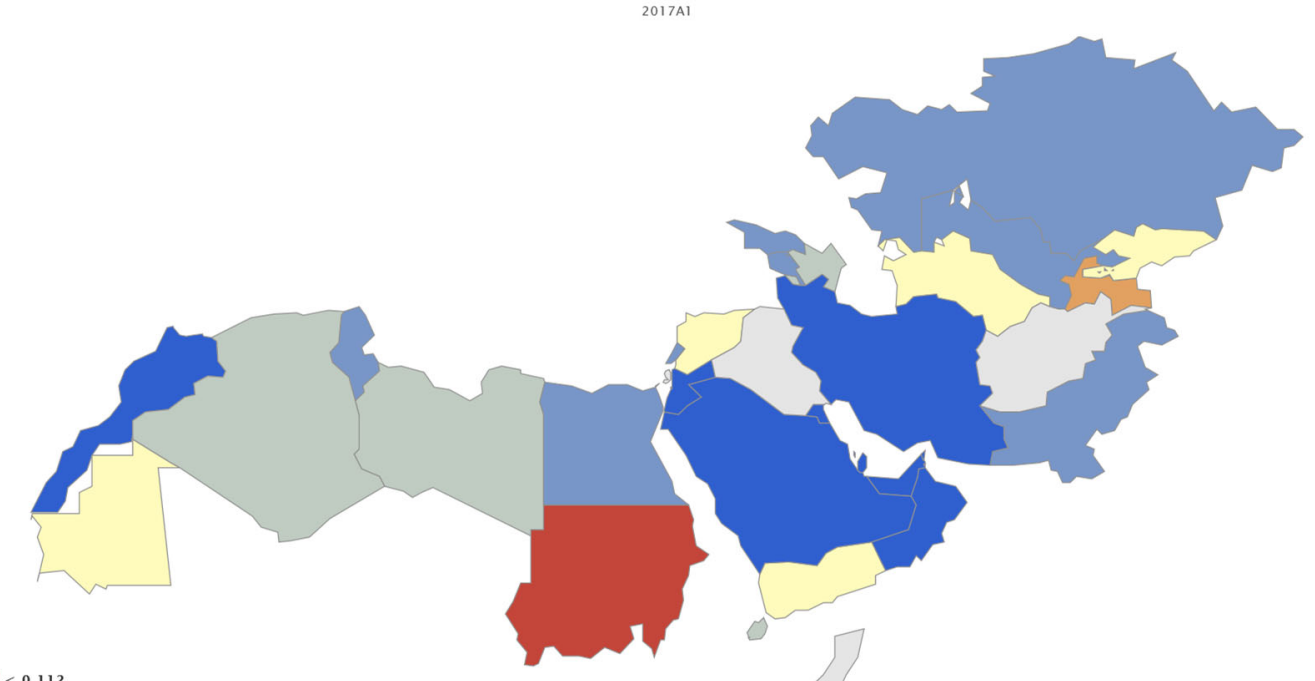

불 $<0.1112$ to 0.111

0.117 to 0.144

0.144 to 0.22

0.220 to 0.34

Appendix V. Figure 2. Financial Institutions Development in MCD Countries (2017)

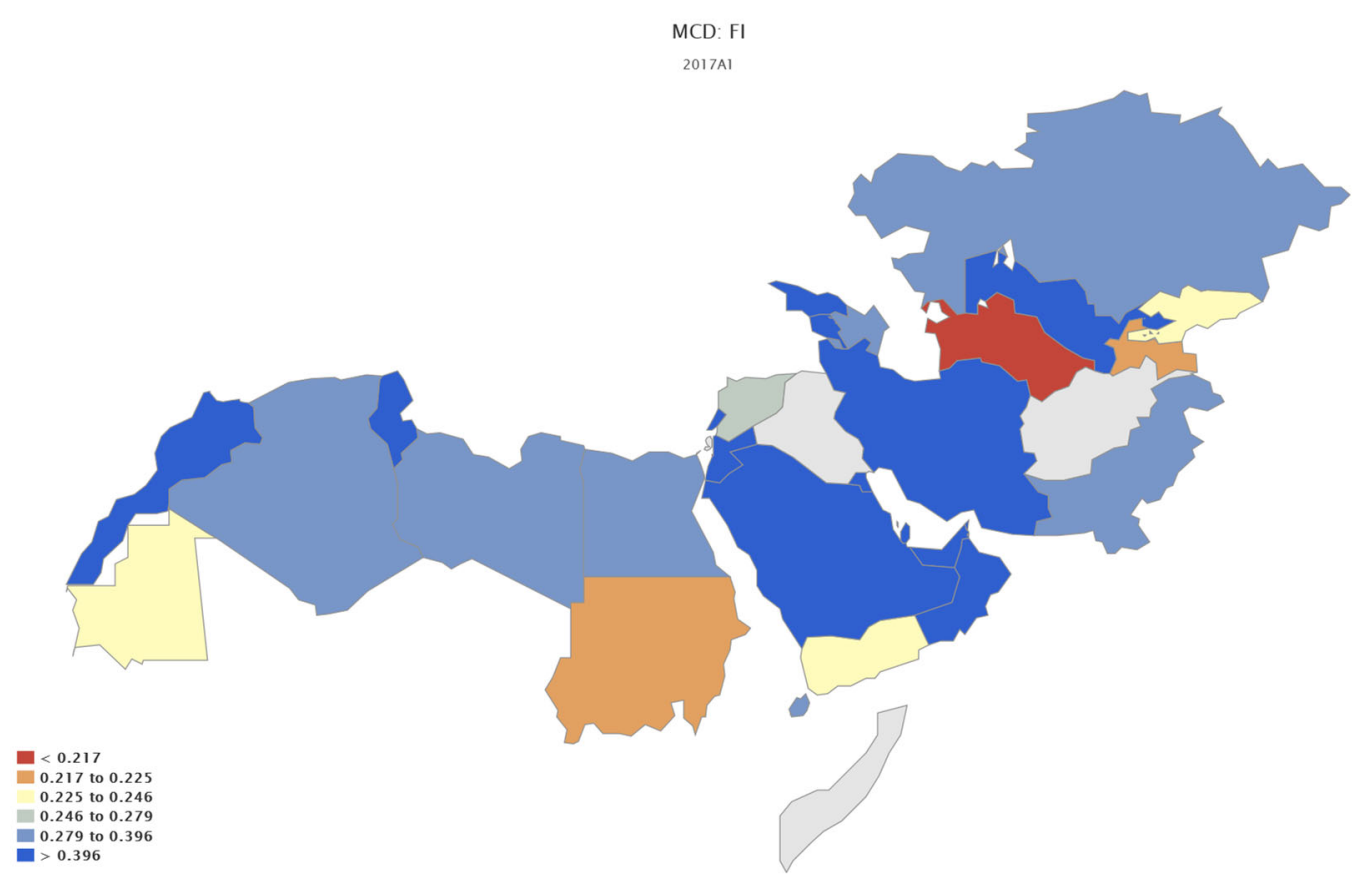

Source: Financial Development Index Database. 


\section{Appendix VI. Selected Countries' Monetary Policy/Inflation Reports-Main Content}

\begin{tabular}{|c|c|c|c|c|c|c|c|c|c|c|c|}
\hline \multirow[b]{2}{*}{ Central Bank } & \multirow[b]{2}{*}{$\begin{array}{l}\text { Title \& Frequency } \\
\text { of the Report }\end{array}$} & \multirow[b]{2}{*}{ Publication Date } & \multicolumn{9}{|c|}{ Core Content } \\
\hline & & & $\begin{array}{l}\text { International } \\
\text { developments }\end{array}$ & $\begin{array}{c}\begin{array}{c}\text { Inflation } \\
\text { developments \& } \\
\text { forecasts }\end{array} \\
\end{array}$ & $\begin{array}{c}\text { Economic } \\
\text { developments } \\
\text { \& forecasts } \\
\end{array}$ & $\begin{array}{l}\text { Labor } \\
\text { Market }\end{array}$ & $\begin{array}{c}\text { Financial } \\
\text { Markets/ } \\
\text { Conditions }\end{array}$ & $\begin{array}{l}\text { Fiscal } \\
\text { Policy }\end{array}$ & $\begin{array}{c}\text { Assumptions \& } \\
\text { risks }\end{array}$ & $\begin{array}{c}\text { Inflation Fan } \\
\text { Chart/ } \\
\text { Forecast } \\
\end{array}$ & $\begin{array}{c}\text { GDP } \\
\text { Fan Chart/ } \\
\text { Forecast }\end{array}$ \\
\hline $\begin{array}{l}\text { Central Bank of } \\
\text { Tunisia }\end{array}$ & $\begin{array}{l}\text { "Evolutions } \\
\text { Economiques et } \\
\text { Monétaires et } \\
\text { Perspectives à } \\
\text { Moyen Terme" } \\
\text { Quarterly }\end{array}$ & $\begin{array}{l}\text { May } 2019 \\
\text { https://www.bct.gov.tn/bct/siteprod/ } \\
\text { page.jsp?id=76 }\end{array}$ & $\sqrt{ }$ & $\sqrt{ }$ & $\sqrt{ }$ & & $\sqrt{ }$ & & $\sqrt{ }$ & & \\
\hline \multicolumn{12}{|c|}{ Countries with a MPCC } \\
\hline $\begin{array}{l}\text { Central Bank of } \\
\text { Armenia }\end{array}$ & $\begin{array}{l}\text { Inflation Report } \\
\text { Quarterly }\end{array}$ & $\begin{array}{l}\text { 2019Q1 } \\
\text { https://www.cba.am/en/SitePages/m } \\
\text { p2019_report.aspx }\end{array}$ & $\sqrt{ }$ & $\sqrt{ }$ & $\sqrt{ }$ & $\sqrt{ }$ & $\sqrt{ }$ & $\sqrt{ }$ & $\sqrt{ }$ & & \\
\hline Bank of Ghana & $\begin{array}{l}\text { Monetary Policy } \\
\text { Report } \\
\text { 4-6 per year }\end{array}$ & $\begin{array}{l}\text { March } 2019 \\
\text { https://www.bog.gov.gh/monetary- } \\
\text { policy/monetary-policy-reports }\end{array}$ & $\sqrt{ }$ & $\sqrt{ }$ & $\sqrt{ }$ & & $\sqrt{ }$ & & & & \\
\hline $\begin{array}{l}\text { Central Bank of } \\
\text { Kenya }\end{array}$ & $\begin{array}{l}\text { Biannual Report of } \\
\text { the Monetary } \\
\text { Policy Committee }\end{array}$ & $\begin{array}{l}\text { April } 2018 \\
\text { https://www.centralbank.go.ke/repor } \\
\text { ts/monetary-policy-reports/ }\end{array}$ & $\sqrt{ }$ & & $\sqrt{ }$ & & $\sqrt{ }$ & & & & \\
\hline $\begin{array}{l}\text { National Bank } \\
\text { of Ukraine }\end{array}$ & $\begin{array}{l}\text { Inflation Report } \\
\text { Quarterly }\end{array}$ & $\begin{array}{l}\text { April } 2019 \\
\text { https://bank.gov.ua/control/en/publis } \\
\text { h/category?cat_id=16036612 }\end{array}$ & $\sqrt{ }$ & $\sqrt{ }$ & $\sqrt{ }$ & $\sqrt{ }$ & $\sqrt{ }$ & $\sqrt{ }$ & $\sqrt{ }$ & & \\
\hline \multicolumn{12}{|c|}{ Selected Advanced Economies (Inflation Targeters) } \\
\hline Bank of Canada & $\begin{array}{l}\text { Monetary Policy } \\
\text { Report } \\
\text { Quarterly }\end{array}$ & $\begin{array}{l}\text { July } 2019 \\
\text { https://www.bankofcanada.ca/public } \\
\text { ations/mpr/ }\end{array}$ & $\sqrt{ }$ & $\sqrt{ }$ & $\sqrt{ }$ & & $\sqrt{ }$ & & $\sqrt{ }$ & 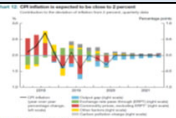 & \\
\hline $\begin{array}{l}\text { Czech National } \\
\text { Bank }\end{array}$ & $\begin{array}{l}\text { Inflation Report } \\
\text { Quarterly }\end{array}$ & $\begin{array}{l}\text { May } 2019 \\
\text { https://www.cnb.cz/en/monetary- } \\
\text { policy/inflation-reports/Inflation- } \\
\text { Report-II-2019/ }\end{array}$ & $\sqrt{ }$ & $\sqrt{ }$ & $\sqrt{ }$ & $\sqrt{ }$ & $\sqrt{ }$ & $\sqrt{ }$ & $\sqrt{ }$ & $=$ & $\underbrace{}_{1}$ \\
\hline $\begin{array}{l}\text { Bank of } \\
\text { England }\end{array}$ & $\begin{array}{l}\text { Inflation Report } \\
\text { Quarterly }\end{array}$ & $\begin{array}{l}\text { May } 2019 \\
\text { https://www.bankofengland.co.uk/in } \\
\text { flation-report/2019/may-2019 }\end{array}$ & $\sqrt{ }$ & $\sqrt{ }$ & $\sqrt{ }$ & $\sqrt{ }$ & $\sqrt{ }$ & & $\sqrt{ }$ & 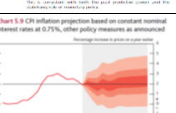 & $z^{2}$ \\
\hline $\begin{array}{l}\text { Reserve Bank } \\
\text { of New Zealand }\end{array}$ & $\begin{array}{l}\text { Monetary Policy } \\
\text { Statement } \\
\text { Quarterly }\end{array}$ & $\begin{array}{l}\text { May } 2019 \\
\text { https://www.rbnz.govt.nz/monetary- } \\
\text { policy/monetary-policy-statement }\end{array}$ & $\sqrt{ }$ & $\sqrt{ }$ & $\sqrt{ }$ & $\sqrt{ }$ & $\sqrt{ }$ & $\sqrt{ }$ & $\sqrt{ }$ & (n) & 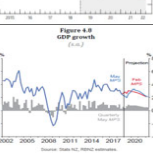 \\
\hline
\end{tabular}




\begin{tabular}{|c|c|c|c|c|c|c|c|c|c|c|c|}
\hline \multirow[b]{2}{*}{ Central Bank } & \multirow[b]{2}{*}{$\begin{array}{l}\text { Title \& Frequency } \\
\text { of the Report }\end{array}$} & \multirow[b]{2}{*}{ Publication Date } & \multicolumn{9}{|c|}{ Core Content } \\
\hline & & & $\begin{array}{l}\text { International } \\
\text { developments }\end{array}$ & $\begin{array}{c}\text { Inflation } \\
\text { developments \& } \\
\text { forecasts }\end{array}$ & $\begin{array}{c}\text { Economic } \\
\text { developments } \\
\& \text { forecasts }\end{array}$ & $\begin{array}{c}\text { Labor } \\
\text { Market }\end{array}$ & $\begin{array}{c}\text { Financial } \\
\text { Markets/ } \\
\text { Conditions } \\
\end{array}$ & $\begin{array}{l}\text { Fiscal } \\
\text { Policy } \\
\end{array}$ & $\begin{array}{l}\text { Assumptions } \\
\text { \& risks } \\
\end{array}$ & $\begin{array}{c}\text { Inflation Fan } \\
\text { Chart/ } \\
\text { Forecast } \\
\end{array}$ & $\begin{array}{c}\text { GDP Fan } \\
\text { Chart/ } \\
\text { Forecast }\end{array}$ \\
\hline \multicolumn{12}{|c|}{ Selected Emerging Markets Economies (Inflation Targeters) } \\
\hline $\begin{array}{l}\text { Banco } \\
\text { Central do } \\
\text { Brasil }\end{array}$ & $\begin{array}{l}\text { Inflation Report } \\
\text { Quarterly }\end{array}$ & $\begin{array}{l}\text { June } 2019 \\
\text { https://www.bcb.gov.br/en/publicatio } \\
\text { ns /inflationreport }\end{array}$ & 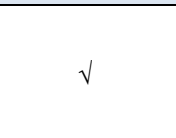 & 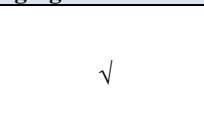 & 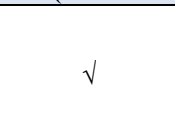 & $\checkmark$ & $\sqrt{ }$ & v & $\sqrt{ }$ & 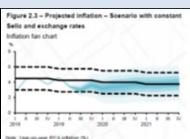 & \\
\hline $\begin{array}{l}\text { Reserve } \\
\text { Bank of India }\end{array}$ & $\begin{array}{l}\text { Monetary Policy } \\
\text { Report } \\
\text { Biannual }\end{array}$ & $\begin{array}{l}\text { April } 2019 \\
\text { https://rbi.org.in/Scripts/HalfYearlyP } \\
\text { ublications.aspx?head=Monetary } \\
\text { Policy Report }\end{array}$ & v & v & v & $\checkmark$ & $\checkmark$ & v & $v$ & & \\
\hline $\begin{array}{l}\text { Central Bank } \\
\text { of Russia }\end{array}$ & $\begin{array}{l}\text { Monetary Policy } \\
\text { Report } \\
\text { Quarterly }\end{array}$ & $\begin{array}{l}\text { June } 2019 \\
\text { https://www.cbr.ru/eng/publ/ddcp/ }\end{array}$ & $\sqrt{ }$ & v & v & $\checkmark$ & $\checkmark$ & v & v & & \\
\hline $\begin{array}{l}\text { Central Bank } \\
\text { of the } \\
\text { Republic of } \\
\text { Turkey }\end{array}$ & $\begin{array}{l}\text { Inflation Report } \\
\text { Quarterly }\end{array}$ & $\begin{array}{l}\text { April } 2019 \\
\text { http://www.tcmb.gov.tr/wps/wcm/co } \\
\text { nnect/EN/TCMB+EN//ain+Menu/P } \\
\text { ublications/Reports/Inflation+Report/ }\end{array}$ & v & $v$ & $v$ & v & v & v & v & ती: & \\
\hline \multicolumn{12}{|c|}{ Other MCD Countries } \\
\hline $\begin{array}{l}\text { Central Bank } \\
\text { of Egypt }\end{array}$ & $\begin{array}{l}\text { Monetary Policy } \\
\text { Report } \\
\text { Quarterly }\end{array}$ & $\begin{array}{l}\text { December } 2018 \\
\text { https://www.cbe.org.eg/en/Monetary } \\
\text { Polic//Pages/MonetaryPolicyReport. } \\
\text { aspx }\end{array}$ & v & v & v & & & & & 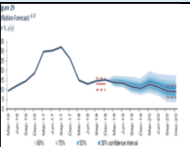 & \\
\hline $\begin{array}{l}\text { National } \\
\text { Bank of } \\
\text { Georgia }\end{array}$ & $\begin{array}{l}\text { Monetary Policy } \\
\text { Report } \\
\text { Quarterly }\end{array}$ & $\begin{array}{l}\text { May } 2019 \\
\text { https://www.nbg.gov.ge/index.php?m } \\
=349 \& \text { lng=eng }\end{array}$ & $\checkmark$ & v & v & $\sqrt{ }$ & $\checkmark$ & & $\sqrt{ }$ & $x^{2}=$ & \\
\hline $\begin{array}{l}\text { National } \\
\text { Bank of } \\
\text { Kazakhstan }\end{array}$ & $\begin{array}{l}\text { Inflation Report } \\
\text { Quarterly }\end{array}$ & $\begin{array}{l}\text { June } 2019 \\
\text { https://nationalbank.kz/?docid=3335 } \\
\text { \&switch=english }\end{array}$ & $\checkmark$ & $\sqrt{ }$ & v & v & $\sqrt{ }$ & $\checkmark$ & v & & \\
\hline $\begin{array}{l}\text { Bank Al- } \\
\text { Maghrib }\end{array}$ & $\begin{array}{l}\text { Monetary Policy } \\
\text { Report } \\
\text { Quarterly }\end{array}$ & $\begin{array}{l}\text { June } 2019 \\
\text { http:///www.bkam.ma/en/Publications } \\
\text {-statistics-and-research/Analysis-and- } \\
\text { reference-documents/Report-on- } \\
\text { monetary-policy }\end{array}$ & $\sqrt{ }$ & $\sqrt{ }$ & $\sqrt{ }$ & $\sqrt{ }$ & $\sqrt{ }$ & $\sqrt{ }$ & $\sqrt{ }$ & 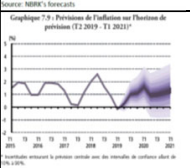 & $\sum_{m=1}$ \\
\hline
\end{tabular}

Sources: Central banks' websites and the authors. 


\section{REFERENCES}

Adrian, T., D. Laxton, and M. Obstfeld (eds). 2018. "Advancing the Frontiers of Monetary Policy," Washington, DC: International Monetary Fund.

Bernanke, B.S., and A.S. Blinder. 1992. "The Federal Funds Rate and the Channels of Monetary Transmission", The American Economic Review, Vol. 82, Issue 4, September.

Blanchard, O., and J. Gali. 2007. "The Macroeconomic Effects of Oil Shocks: Why are the 2000s so Different from the 1970s," NBER Working Paper No. 13368, November.

Boivin, J., M.T. Kiley, and F.S. Mishkin, 2010, "How Has the Monetary Transmission Mechanism Evolved Over Time?" Finance and Economics Discussion Series, Divisions of Research and Statistics and Monetary Affairs, Federal Reserve Board, Washington, D.C, (2010).

Bordo, M.D. 2003. “Exchange Rate Regime Choice in Historical Perspective,” IMF Working Paper No. 03/160, August.

Borio, C., and W. Fritz. 1995. "The Response of Short-Term Bank Lending Rates to Policy Rates: A Cross-Country Perspective”, BIS Working Paper No. 27, May.

Brandao-Marques, L., G. Gelos, T. Harjes, R. Sahay, and Y. Xue. 2020. "Monetary Policy Transmission in Emerging Markets and Developing Economies," IMF Working Paper No. 20/35, February.

Carare, A., A. Schaechter, M. Stone, and D. Zelmer. 2002. "Establishing Initial Conditions in Support of Inflation Targeting," IMF Working Paper 02/102, June.

Christiano, L.J., M. Eichenbaum, and C.L. Evans. 1996. “The Effects of Monetary Policy Shocks: Evidence from the Flow of Funds," Review of Economic and Statistics, Vol. 78, No. 1, February. 2005. "Nominal Rigidities and the Dynamic Effects of a Shock to Monetary Policy," Journal of Political Economy, Vol. 113, No. 1, February.

Cottarelli, C., and A. Kourelis. 1994. "Financial Structure, Bank Lending Rates, and the Transmission Mechanism of Monetary Policy”, IMF Working Paper No. 94/39, March.

De Bondt, G. 2002. "Retail Bank Interest Rate Pass-Through: New Evidence at the Euro Area Level", ECB Working Paper 136.

Donnay, M., and H. Degryse. 2001. "Bank Lending Rate Pass-Through and Differences in the Transmission of a Single EMU Monetary Policy", Discussion Paper, Center for Economic Studies, K.U. Leuven. 
Eichengreen, B., P. Masson, H. Bredenkamp, and others. 1998. "Exit Strategies: Policy Options for Countries Seeking Greater Exchange Rate Flexibility," IMF Occasional Paper No. 168.

El Hamiani Khatat Mariam. 2018. "Monetary Policy and Models of Currency Demand," IMF Working Paper No. 18/28, February. , and R. Veyrune. 2019. "Liquidity Management under Fixed Exchange Rate with Open Capital Account," IMF Working Paper No. 19/58, March.

Freedman, C. and I. Ötker-Robe. 2009. "Country Experiences with the Introduction and Implementation of Inflation Targeting," IMF Working Paper No. 09/161, July. . 2010. "Important Elements for Inflation Targeting for Emerging Economies," IMF Working Paper No. 10/113, May.

Gigineishvili, N. 2011. "Determinants of Interest Rate Pass-Through: Do Macroeconomic Conditions and Financial Market Structure Matter?” IMF Working Paper No. 11/176, July.

International Monetary Fund (IMF). 2011. Annual Report on Exchange Arrangements and Exchange Restrictions-2010 (Washington D.C: International Monetary Fund). . 2014. “Conditionality in Evolving Monetary Policy Regimes,” March. . 2015. "Evolving Monetary Policy Frameworks in Low-Income and Other Developing Countries," October.

. 2018. Annual Report on Exchange Arrangements and Exchange Restrictions-2017 (Washington D.C: International Monetary Fund).

Kenen, P.B., 1969. "The Theory of Optimum Currency Areas: An Eclectic View," in Monetary Problems of the International Economy, R.A. Mundell and A. Swoboda (eds.). Chicago: University of Chicago Press.

Kydland, F., and E. Prescott. 1977. "Rules Rather than Discretion: The Inconsistency of Optimal Plans," Journal of Political Economy 85, No. 3, 473-92, June.

Laurens, B.J., K. Eckhold, D. King, N. Maehle, A. Naseer, and A. Durré. 2015. “The Journey to Inflation Targeting: Easier Said than Done. The Case for Transitional Arrangements along the Road," IMF Working Paper No. 15/136, June.

Masson, P., M. Savastano, and S. Sharma. 1997. "The Scope for Inflation Targeting in Developing Countries,” IMF Working Paper No. 97/130, October.

McKinnon, R. 1963. “Optimal Currency Areas,” American Economic Review, 53, 717-24, September. 
Mishkin, F.S. 2006. “Monetary Policy Strategy: How Did We Get There?” NBER Working Paper No. 12515, September.

Mishra, P., P.J. Montiel, and A. Spilimbergo. 2012. "Monetary Transmission in Low-Income Countries: Effectiveness and Policy Implications," IMF Economic Review, Vol. 60, Issue 2, 270-302, July.

Mojon, B. 2000. "Financial Structure and the Interest Rate Channel of ECB Monetary Policy," ECB Working Paper No. 40, November.

Mundell, R. 1961. “A Theory of Optimum Currency Areas,” American Economic Review, 51, 657-61, September.

Ötker-Robe, I., and D. Vávra. 2007. "Moving to Greater Exchange Rate Flexibility, Operational Aspects Based on Lessons from Detailed Country Experiences," IMF Occasional Paper No. 256.

Sahay, R., M. Čihák, P. N’Diaye, A. Barajas, R. Bi, D. Ayala, Y. Gao, A. Kyobe, L. Nguyen, C. Saborowski, K. Svirydzenka, and S.R. Yousefi. 2015. "Rethinking Financial Deepening: Stability and Growth in Emerging Markets," IMF Staff Discussion Note, No. 15/08, May.

Sims, C. A. 1992. "Interpreting the Macroeconomic Time Series Facts: The Effects of Monetary Policy," European Economic Review 36, 975-1000.

Stone, M. 2003. “Inflation Targeting Lite,” IMF Working Paper No. 03/12, January.

Toolsema, L., J. Sturm, and J. Dehaan. 2002. "Convergence of Pass-Through from Money Market to Lending Rates in EMU Countries: New Evidence,” University of Groningen, Centre for Economic Research, Netherlands, CCSO Working Papers.

Yeyati, E. L., Sturzenegger, F., \& Reggio, I. 2010. "On the Endogeneity of Exchange Rate Regimes,” European Economic Review 54, 659-677. 